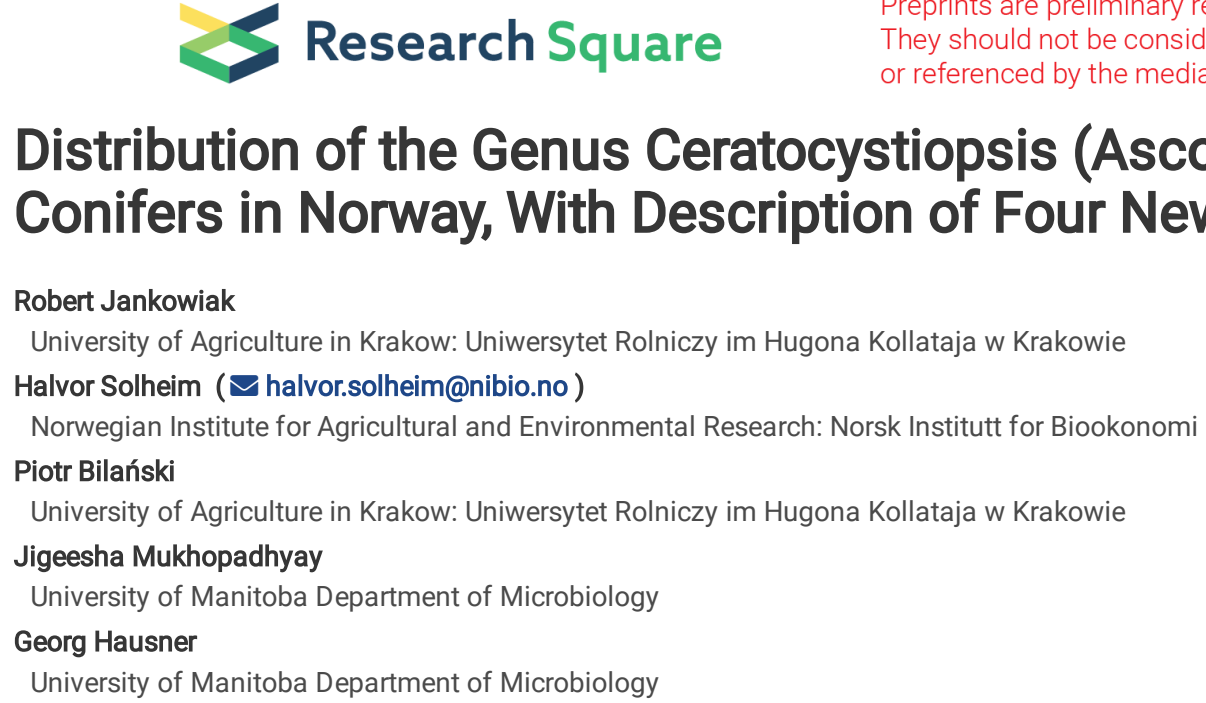

\title{
Distribution of the Genus Ceratocystiopsis (Ascomycota, Ophiostomatales) on Conifers in Norway, With Description of Four New Species
}




\section{Abstract}

The genus Ceartocystiopsis includes ascomycetes fungi belonging to the Ophiostomatales that are not well recognized in the world. Described species so far have been found mainly in association with bark beetles in the Northern Hemisphere. The aims of this study were therefore to survey of distribution of species of Ceratocystiopsis associated with bark beetles infesting Picea abies and Pinus sylvestris in Norway. Adults for 22 different bark beetle species were collected from 13 stands in Norway. During this study, we recovered 126 isolates showing affinities to Ceratocystiopsis representing six species, including two described and four undescribed taxa. The four undescribed taxa collected during this work were characterised based on their morphological characteristics and multi-gene phylogenies. Herein, we describe these new species as Ceratocystiopsis chalcographii sp. nov., Ceratocystiopsis debeeria sp. nov., Ceratocystiopsis norroenii sp. nov. and Ceratocystiopsis troendelagii sp. nov. Ceratocystiopsis norroenii and $C$. rollhanseniana were the most frequently isolated species although the latter species had a much wider vector range. This study expands our knowledge about the taxonomy and species diversity of Ceratocystiopsis and beetle-fungus relationships.

\section{Introduction}

Ceratocystiopsis was established by Upadhyay and Kendrick (1975) based on the morphological description of Ophiostoma minutum by Siemaszko (1939). Siemaszko (1939) based O. minutum on the characterization of perithecia found on the wood of Picea abies infested with Ips typographus in the Białowieża Forest (Poland), Siemaszko did not describe a conidial state for this fungus. The taxonomy of this group has a turbulent history, and species of Ceratocystiopsis (Ascomycota, Ophiostomatales, Ophiostomataceae) have been accommodated in various genera including Ceratocystiopsis (Upadhyay 1981; Marmolejo and Butin 1990; Hsiau and Harrington 1997; Zipfel et al. 2006; Strzałka et al. 2020; Nel et al. 2021), Ceratocystis (Griffin 1968; Olchowecki and Reid 1974), Cornuvesica (Viljoen et al. 2000), and Ophiostoma (Siemaszko 1939; Hausner et al. 1993, 2003; Kirschner and Oberwinkler 1999). Important historical developments in the taxonomy of Ceratocystiopsis include: 1) erecting the genus Ceratocystiopsis for species that have falcate ascospores with sheaths and short perithecial necks (Upadhyay and Kendrick (1975); 2) reducing Ceratocystiopsis to synonymy with Ophiostoma, based on partial SSU and LSU rDNA sequences (Hausner et al. 1993); 3) re-instating Ceratocystiopsis to accommodate taxa that have short ascomatal necks, produce falcate ascospores with sheaths and have Hyalorhinocladiella (occasionally sporothrix-like) anamorphs. The later was supported by molecular data that combined partial nuclear LSU and $\beta$-tubulin gene sequences (Zipfel et al. 2006). Currently, Ceratocystiopsis is one of nine more or less clearly defined genera in the Ophiostomataceae (De Beer and Wingfield 2013; De Beer et al. 2013a, 2013b, 2016; Hyde et al. 2020).

As currently circumscribed Ceratocystiopsis accommodates 20 recognized species (De Beer et al. 2013a; Strzałka et al. 2020; Nel et al. 2021; Chang et al. 2021), which are characterized by ascocarps that have short necks, and produce falcate ascospores surrounded by a hyaline sheath (De Beer and Wingfield 2013). According to De Beer and Wingfield (2013), Ceratocystiopsis species besides falcate ascospores (type E, F) may also produce cucullate ascospores (typ G), in addition Ceratocystiopsis spp. typically have hyalorhinocladiella-like asexual morphs (De Beer and Wingfield 2013).

The genus Ceratocystiopsis has a wide geographic distribution, including records for Africa (Nel et al. 2021), Asia (e.g., Yamaoka et al. 1997; Wang et al. 2020; Chang et al. 2021), Europe (e.g., Hausner et al. 1993; Kirisits 2004, Jankowiak 2005; Linnakoski et al. 2012;) and North America (Olchowecki and Reid 1974; Bridges and Perry 1987; Marmolejo and Butin 1990; Hsiau and Harrington 1997; Hausner et al. 2003). They are abundant in the Northern Hemisphere, especially in conifer ecosystems in Europe and North America. The most frequently reported member of this genus is Ceratocystiopsis minuta. This species based on reports appears to be globally widespread, although Plattner et al. (2009) based on molecular phylogenetic analyses showed that strains from Europe and Asia assigned to $C$. minuta can be arranged into at least three well defined lineages (clades $C$, D, and E). In addition, "C. minuta-like" strains from North America failed to group within those lineages that accommodated $C$. minuta strains from Europe and Asia. So, $C$. minuta s.l. is a species complex that probably includes several cryptic species that have yet to be described. In the original description, type material was not designated for $C$. minuta (Siemaszko 1939). For this reason, Reid and Hausner (2010) proposed the epitypification of Ceratocystiopsis minuta based on UAMH 11218 (= a dried culture of UM1532 (=WIN(M)1532), originally isolated from Picea abies infested by Ips typographus in the Biebrzański National Park (Poland). With reference to the work of Plattner et al. (2009), UM1532 (=RJ705) belongs to clade D.

Ceratocystiopsis species occupy a relatively narrow range of habitats. The greatest number of species have been recorded on conifers in association with bark and wood boring beetles (e.g., Olchowecki and Reid 1974; Hsiau and Harrington 1997; Yamaoka et al. 1997; Kirisits 2004; Linnakoski et al. 2012; Nel et al. 2021). Other species have been described from hardwood trees (Olchowecki and Reid 1974; Li et al. 2018, Strzałka et al. 2020). Very little is known about the distribution of Ceratocystiopsis species in Norway. To date, only C. minuta and C. rollhanseniana have been described from Norway. The first of them has been isolated from Picea abies infested by Ips typographus (Solheim 1986, 1992, 1993) while the second species has been collected from beetle galleries in a standing tree of Pinus sylvestris (Hausner et al. 2003).

A survey of bark beetles and their associated fungi on conifers in Norway was conducted from October 2014 to September 2015 . Among the fungi recovered from this study many isolates obtained from various species of bark beetles, and their galleries resembled species of Ceratocystiopsis. The aim of this study was to characterize the morphology, phylogenetic affinities, and taxonomy of Ceratocystiopsis isolates found in Norway and to resolve the phylogenetic relationships between these fungi and closely related known species within the genus Ceratocystiopsis. In addition, this study provides new insights on the abundance and distribution of Ceratocystiopsis species in Norway.

\section{Materials And Methods}

\section{Fungal isolates}

Between October 2014 and September 2015, 22 species of bark beetles were collected from several locations in Norway (Table 1, Fig. 1). The sampled bark beetles represented the following genera, Cryphalus saltuarius Crypturgus cinerus, Crypturgus pusillus, Dryocoetes autographus, Dryocoetes hectographus, 
Hylastes brunneus, Hylastes cunicularis, Hylurgops palliatus, Ips acuminatus, Ips sexdentatus, Orthotomicus laricis, Orthotomicus proximus, Orthotomucus suturalis, Pityogenes bidentatus, Pityogenes chalcographus, Pityogenes quadridens, Pityogenes saalasi, Pityophthorus micrographus, Polygraphus poligraphus, Polygraphus subopacus, Tomicus piniperda and Tryopdendron lineatum. The bark beetles were collected by hand from Picea abies and Pinus sylvestris. Bark beetle adults were excised from the bark and galleries with sterilized tweezers and stored individually in sterile $1.5 \mathrm{ml}$ Eppendorf tubes for later fungal isolations. Each bark beetle was divided into three parts, elytra, head and the rest, before placing the parts in three separate Petri dishes with malt extract agar [MEA; $6.25 \mathrm{~g}$ malt Bacto ${ }^{\mathrm{TM}}$ agar powder (Beckton, Dickinson, Sparks, USA), $10 \mathrm{~g}$ agar (bactoagar powder from VWR International, Leuven, Belgium), 0.5 I deionized water] without any cycloheximide. Emerging cultures were purified by transferring small pieces of mycelium or spore masses from individual colonies to fresh MEA. Fungi were incubated at $20^{\circ} \mathrm{C}$, then subcultured onto $2 \%$ MEA and stored at $4{ }^{\circ} \mathrm{C}$. After two weeks of incubation, the purified fungal cultures were grouped into morphotypes based on their morphological characteristics. Depending on the number of isolates belonging to the same morphotype, 2-19 isolates per morphotype were chosen for molecular identification (Table 2).

The cultures are maintained in the culture collection of Norwegian Institute of Bioeconomy (NIBIO), Norway. Ex-type isolates of new species described in this study were deposited in the collection of the Westerdijk Fungal Biodiversity Institute (CBS), Utrecht, The Netherlands, and in the culture collection (CMW) of the Forestry and Agricultural Biotechnology Institute (FABI), University of Pretoria, Pretoria, South Africa. Type specimens were deposited in the Mycological Herbarium (O), Natural History Museum, University of Oslo, Norway. The types of $C$. neglecta and $C$. rollhanseniana were sourced from the culture collection of the Westerdijk Fungal Biodiversity Institute (CBS), and from the culture collection of the University of Manitoba (WIN) in Canada (Table 2). Taxonomic descriptions and nomenclatural data were registered in MycoBank (www.MycoBank.org) (Robert et al. 2013).

\section{Microscopy and growth studies}

Morphological characters were examined for selected isolates as well as for the herbarium specimens selected as types. Isolates were grown on $2 \%$ Malt Extract Agar (MEA) $\left(20 \mathrm{~g} \mathrm{Bacto}^{\mathrm{Tm}}\right.$ malt extract, $20 \mathrm{~g}$ agar Bacto ${ }^{\mathrm{TM}}$ agar powder (Becton Dickinson and Company, Franklin Lakes, USA) in $1 \mathrm{I}$ deionized water). In attempts to induce the formation of ascomata, autoclaved twigs of host trees including the bark were placed at the centres of agar plates containing MEA. Fungal cultures were derived from single conidia. To promote the production of ascomata, single conidial isolates were crossed in all possible combinations, following the technique described by Grobbelaar et al. (2009). These cultures were incubated at $25^{\circ} \mathrm{C}$ and monitored regularly for the appearance of fruiting structures.

Morphological features were examined by mounting fungal tissue in $80 \%$ lactic acid on glass slides, and fruiting structures were observed using a Nikon Eclipse 50 i microscope (Nikon ${ }^{\circledR}$ Corporation, Tokyo, Japan) with an Invenio 5 S digital camera (DeltaPix ${ }^{\circledR}$, Maalov, Denmark) to capture photographic images. Microscopy followed the technique described by Kamgan Nkuekam et al. (2011). Colour designations were based on the colour charts of Kornerup and Wanscher (1978).

For each taxonomically relevant structure, fifty measurements were made, when possible, using the Coolview 1.6 .0 software (Precoptic ${ }^{\circledR}$, Warsaw, Poland). Averages, ranges and standard deviations were calculated for the measurements, and these are presented in the format '(min-)(mean-SD) $($ mean+SD)($\max )^{\prime}$.

Growth characteristics for the novel species were determined by analysing the radial growth for two isolates (two for each species). Agar disks (5 mm diam.) were cut from the actively growing margins of fungal colonies and these disks were placed at the centres of plates containing $2 \%$ MEA. Four replicate plates for each of the six putative new species were incubated at temperatures between 5 , and $35^{\circ} \mathrm{C}$ at $5{ }^{\circ} \mathrm{C}$ intervals. The radial growth (two measurements perpendicular to each other per plate) was determined $14 \mathrm{~d}$ after inoculation, and growth rates were calculated as $\mathrm{mm} / \mathrm{d}$.

\section{PCR, sequencing, and phylogenetic analyses}

Morphotypes were initially identified by sequencing the internal transcribed spacer 1 and 2 (ITS1-5.8S-ITS2), internal transcribed spacer 2 and large subunit (ITS2-28S) or $\beta$-tubulin ( $\beta$ T) gene region of representative isolates (Table 2). DNA extractions were performed as described by Aas et al. (2018). For more detailed analysis two loci were also amplified and sequenced and subjected to phylogenetic analyses: calmodulin (CAL), and the translation elongation factor 1-alpha (TEF1-a). The primers used for PCR and sequencing of the various loci were as follows: ITS1-F (Gardes and Bruns 1993) and ITS4 (White et al. 1990) for the ITS region; T10 (O'Donnell and Cigelnik 1997) or Bt2a together with Bt2b (Glass and Donaldson 1995) for $\beta$ T; F-728F (Carbone and Kohn 1999) and EF2 (O'Donnell et al. 1998) were used for TEF1-a; CL1 and CL2a (O'Donnell et al. 2000) or CL3F and CL3R (De Beer et al. 2016) were used for CAL. Protocols for PCR amplification and DNA sequencing were as described previously (Aas et. al 2018).

All phylogenetic analyses were performed independently for each gene partition (Figs. 2-6). Resulting trees were visually compared for topological incongruence. Gene partitions showing no topological incongruences (i.e., ITS1-5.8S-ITS2-28S+ $\beta$ T) were combined and presented as a concatenated construct (Fig. 7).

For phylogenetic analyses, sequence alignments were performed using the online version of MAFFT v7 (Katoh and Standley 2013). The ITS1-5.8S-ITS2, ITS2$28 \mathrm{~S}, \beta T, C A L$, and TEF1-a datasets were aligned using the E-INS-i strategy with a 200PAM/ $\mathrm{K}=2$ scoring matrix, a gap opening penalty of 1.53 and an offset value of 0.00. The alignments were checked manually with BioEdit v.2.7.5 (Hall 1999). The resulting alignments and trees were deposited into TreeBASE (http://purl.org/phylo/treebase/phylows/study/TB2:S28950).

Phylogenetic trees were inferred for each of the datasets using three different methods: Maximum likelihood (ML), Maximum Parsimony (MP) and Bayesian inference $(\mathrm{BI})$. For $\mathrm{ML}$ and $\mathrm{BI}$ analyses, the best-fit substitution models for each aligned dataset were established using the corrected Akaike Information Criterion (AICC) in jModelTest 2.1.10 (Guindon and Gascuel 2003; Darriba et al. 2012). ML analyses were carried out with PhyML 3.0 (Guindon et al. 2010 ), utilizing the Montpelier online server (http://www.atgc-montpellier.fr/phyml/). The ML analysis was combined with bootstrapping (1000 bootstrap

Page 3/23 
pseudoreplicates) to assess node support values and the overall reliability of the tree topology. The best evolutionary substitution models were as follows: GTR+I+G for ITS1-5.8S-ITS2 (-InL = 4817.94), ITS2-28S (-InL = 1452.82) and CAL (-InL = 3350.13); GTR+G for $\beta$ T (-InL = 4368.71) and ITS-LSU+ $\beta$ T (-InL = 9793.62); and HKY+I+G for TEF1-a (-InL = 5374.80).

MP analyses were performed using PAUP* 4.0b10 (Swofford 2003). Gaps were treated as fifth state. Bootstrap analysis (1000 bootstrap replicates) was conducted to determine the levels of confidence for the nodes within the inferred tree topologies. Tree bisection and reconnection (TBR) was selected as the branch swapping option. The tree length ( $\mathrm{TL}$ ), Consistency Index (Cl), Retention Index (RI), Homoplasy Index (HI) and Rescaled Consistency Index (RC) were recorded for each analysed dataset after the trees were generated.

$\mathrm{BI}$ analyses using Markov Chain Monte Carlo (MCMC) methods were carried out with MrBayes v3.1.2 (Ronquist and Huelsenbeck 2003). Four MCMC chains were run in parallel for 10 million generations applying the best-fit model for each dataset. Trees were sampled every $100^{\text {th }}$ generations, resulting in 100,000 trees. Tracer v1.4.1 (Rambaut and Drummond 2007) was utilized to determine the burn-in value for each dataset. The remaining trees were utilized to generate a $50 \%$ majority rule consensus tree, which allowed for calculating posterior probability values for the nodes.

\section{Results}

\section{Collections of bark beetles and fungi}

Altogether 22 bark beetle species were collected from Norway during this study (Table 3). Among the bark beetles carrying Ceratocystiopsis species only $P$. chalcographus occurred on both pine and spruce. Five bark beetle species with Ceratocystiopsis species were found on pine, while four bark beetle species were encountered only on spruce. The isolations from bark beetles yielded a total of 126 isolates resembling Ceratocystiopsis spp.

In total, 126 Ceratocystiopsis spp. isolates were obtained from 459 sampled beetles (Table 3). Fifty isolates were collected from I. acuminantus, 21 isolates were collected from 0 . proximus, 15 isolates were collected from $P$. chalcographus, and 12 isolates were collected from $C$. cinereus. The additional twentyeight isolates were collected from H. palliatus, P. saalasi, Pol. subopacus, C. pusillus, P. bidentatus, and P. quadridens (Table 3 ). Based on morphological observations the fungal isolates obtained from this study could be arranged into six taxa. Fifty-five isolates represented taxon 6 , were isolated from six different bark beetles. This taxon was the most frequently encountered on P. bidentatus ( $72 \%$ ) and 0 . proximus (70\%). The frequency of occurrence of this taxon on C. cineraeus was also relatively high (40\%). Fifty isolates belonged to taxon 2 . This taxon was found only in high frequency on $I$. acuminatus (54\%). The remaining 16 isolates represented four Ceratocystiopsis taxa and were collected from 1 or 2 different beetle species (Table 3). The frequency of occurrence of these species was less than $11 \%$ (Table 3).

\section{Phylogenetic Analyses}

Alignments for the ITS1-5.8S-ITS2 data set contained 738 characters; for the ITS2-28S data 496 characters; for the CAL data 613 characters; for the TEF1- $\alpha$ data 785 characters; for the $\beta$ T data 526 characters for the ITS1-5.8S-ITS2-28S+ $\beta$ T data 1839 characters (including gaps). The exon/intron arrangement of the CAL data included intron 3, exon 4, intron 4, exon 5 intron 5, exon 6 and intron 6 . The exon/intron arrangement of the TEF1-a data included intron 3, exon 4, intron 4 and exon 5 . The aligned $\beta$ T gene region consisted of exons 3 to 6 , interrupted by introns 3,4 and 5 .

DNA sequence data were obtained for 45 isolates representing all six morphological groups represented among the 126 Ceratocystiopsis resembling fungal isolates recovered from 459 sample beetle specimens (Table 2). BLAST analyses of the ribosomal DNA sequences placed the examined isolates in the genus Ceratocystiopsis. Sequences from our 45 representative strains when combined with those of other members of the genus Ceratocystiopsis formed six independent well-supported terminal clades representing six phylogenetic species (Taxa 1-6) in the ITS1-5.8S-ITS2, ITS2-28S, $\beta$ T, CAL and TEF1- $a$ phylogenetic inferences (Figs. 2-6). Based on the phylogenetic analyses of the ITS1-5.8S-ITS2 and ITS2-28S data sets (Figs. 2-3), the isolates emerged as two known and four undescribed taxa of the genus Ceratocystiopsis.

Four isolates recovered from $P$. abies and $P$. sylvestris infested by $P$. chalcographus (i.e., taxon 1 ) in the ITS1-5.8S-ITS2 and ITS2-28S trees grouped in the " $C$. minuta" clade $\mathrm{C}$ as defined by Plattner et al. (2009), this clade includes European and Japanese strains of Ceratocystiopsis minuta s.l. In the $\beta$ T tree, eight isolates of taxon 1 recovered in this study clustered into a distinct monophyletic clade next to a Ceratocystiopsis strain (CMW4352) from Austria and Japanese isolates of Ceratocystiopsis spp. (YCC330 and YCC329) (Fig. 4). Although only poorly supported this clade appears to share a common node with strains assigned to C. minuta s. str. (including UM1532) and C. weihaiensis (Fig. 4).

Nine isolates obtained from $P$. sylvestris infested by I. acuminatus (i.e., taxon 2) in the ITS1-5.8S-ITS2, ITS2-28S, $\beta$ t, CAL, and TEF1-a trees (Figs. 2-6) form a well-supported lineage, distinct from all the other known species of Ceratocystiopsis. Six isolates representing taxon 3 and taxon 4 also form a well-supported lineages distinct from other known species of Ceratocystiopsis (Figs. 2-6). Taxon 3 appears to represent a phylogenetically distinct lineage, potentially sharing ancestry with $C$. neglecta (Figs. 2-4), however the nodes supporting monophyly are only poorly supported. Members of taxon 4 form a linage adjacent to $C$. minima within the ITS2-28S sequences based phylogenetic tree (Fig. 3), however the other dataset do not support monophyly for these two species (Figs. 2, 4 and 7).

The analyses of the combined ITS1-5.8S-ITS2-28S+ $\beta$ T datasets clearly separated Taxa 1 to 4 from the other known species of Ceratocystiopsis and also from each other (Fig. 7). Nineteen isolates of taxon 5 grouped with the ex-type isolate of $C$. rollhanseniana (UM113) and other isolates of this species based on ITS2-28S (Fig. 3). The $\beta$ T , CAL and TEF1-a data also confirmed that those isolates represented C. rollhanseniana (Figs. 4-6). The ITS1-5.8S-ITS2, ITS2-28S, $\beta$ T, CAL and TEF1-a datasets confirmed that four isolates of taxon 6 grouped with ex-type isolate of $C$. neglecta (Figs. 2-6).

\section{Taxonomy}


The morphological characterization and phylogenetic comparisons based on five genetic loci, showed that four herein described morphotypes (taxon 1, 2, 3 and 4) are distinct from each other and from other known taxa in the genus Ceratocystiopsis. Therefore, they are described here as new species:

Ceratocystiopsis chalcographii Jankowiak \& H. Solheim, sp. nov.

MycoBank: 841844

(Fig. 8)

Etymology. The epithet chalcographii (Latin), refers to the species name of the bark beetle vector of this fungus, Pityogenes chalcographus.

Diagnosis: This species is closely related to $C$. minuta and $C$. norroenii. Ceratocystiopsis chalcographii has longer perithecial necks (36-124 $\mu$ m) compared to C. minuta $(20-45 \mu \mathrm{m})$ (Reid and Hausner 2010). Their ostiolar hyphae is also longer (7.7-16.4 vs. to $12 \mu \mathrm{m})$ just as the length of the ascospores (9.9-15 vs. 10-13 $\mu \mathrm{m}$ ) (Reid and Hausner 2010). Ceratocystiopsis chalcographii has obovoid conidia, whereas C. minuta has oblong conidia (Reid and Hausner 2010). Ceratocystiopsis chalcographii has longer conidia $(2.9-6 \mu \mathrm{m})$ compared to $C$. minuta $(2-4 \mu \mathrm{m})$ (Reid and Hausner 2010). In addition, conidiophores of $C$. chalcographii are simple or slightly branched while $C$. minuta produces simple or verticillate to irregular branched conidiophores (Reid and Hausner 2010). Ceratocystiopsis norroenii also produces branched conidiophores, however this taxon could be distinguished from $C$. minuta by oblong and larger conidia $(2.7-5 \times 1.1-2.3$ vs. $2-4 \times 1.2 \mu \mathrm{m})$. In addition, $C$. norroenii does not produce a sexual morph.

Type: Norway, Nannestad, from Pityogenes chalcographus infesting Picea abies, 15 Oct. 2014, H. Solheim and M.E. Waalberg (0-F-259424 holotype; CBS 147954 = CMW 57280 - ex-type culture).

Description: Sexual morph perithecial. Perithecia abundantly produced on media and sterilized spruce twigs, various in shape, bases black, globose or subprolate (46-)55-101(-125) $\mu \mathrm{m}$ diam. Necks black, straight or slightly curved, (36-)55-88(-124) $\mu \mathrm{m}$ long. Diameter of the necks (5.9-)8.2-13(-17) $\mu \mathrm{m}$ at the apex and (20.3-)23.9-32.3(39.7) $\mu \mathrm{m}$ at the base. Ostiolar hyphae present, hyaline, aseptate, straight, tapering extensively towards the apex, $5-8$ in number, (7.7-)9.2-13(-16.4) $\mu \mathrm{m}$ long. Asci not observed. Ascospores one-celled, hyaline, including the sheath falcate in side view (9.9-)11.6-14($15) \times(1-) 1.2-1.6(-1.8) \mu \mathrm{m}$, accumulated in a white-coloured mass at the tip of the neck.

Asexual morphs: hyalorhinocladiella-like.

Hyalorhinocladiella-like morph: conidiophores mononematous, micronematous or semi-macronematous, arising from vegetative hyphae, simple or slightly branched, upright, straight or undulate, producing conidiogenous cells at their apices, (1.7-)6.9-23.4(-40.4) × (0.7-)1-1.8(-2.2) $\mu \mathrm{m}$. Conidiogenous cells integrated, hyaline, blastic, not denticulate. Conidia hyaline, aseptate, obovoid with the upper part swollen, apex round, tapering toward base, sometimes pyriform, no sheath, $(2.9-) 3.6-5(-6) \times(0.9-) 0.9-1.2(-1.9) \mu \mathrm{m}$, no sheath.

Cultures: Colonies with optimal growth at $30^{\circ} \mathrm{C}$ on $2 \%$ MEA with radial growth rate $1.11( \pm 0.05) \mathrm{mm} / \mathrm{d}$. Colonies white, margin smooth, floculose, with white lumps of slimy conidia. Hyphae hyaline to pale grey in colour, reverse pale orange (Kornerup and Wanscher 1978), smooth, submerged in the medium and aerial mycelium abundant, not constricted at the septa, 1-2.6 (mean 1.7 \pm 0.4$) \mu \mathrm{m}$ diam., asexual morph very abundant.

Ecology: Isolated from Pityogenes chalcographus infesting Picea abies and Pinus sylvestris.

Habitat. Picea abies and Pinus sylvestris forests.

Distribution: Currently only known from Norway.

Notes: Ceratocystiopsis chalcographii and $C$. norroenii formed two distinct, well-supported clades within the $C$. minuta group, in which they were closely related to $C$. minuta (Figs. 2-4). They can be both differentiated from $C$. minuta by the morphology of sexual morph as well as morphology of the conidia and conidiophores.

Ceratocystiopsis chalcographii was rarely isolated from bark beetles infesting $P$. abies and $P$. sylvestris (Table 3 ). It was found only in association with $P$. chalcographus on Scots pine in Rendalen and on Norway spruce in Nannestad. This species is one of two Ceratocystiopsis species isolated from $P$. chalcographus (Taxa 1 and 3).

Additional specimen examined: Norway: Rendalen, from Pityogenes chalcographus infesting Pinus sylvestris, 29 Oct. 2014, H. Solheim, (0-F-259425, culture CBS $147955=$ CMW 57282).

\section{Ceratocystiopsis norroenii Jankowiak \& H. Solheim, sp. nov.}

MycoBank: 841845

(Fig. 9)

Etymology. The epithet norroenii (Latin), refers to the word Norrøn, which in norse mythology means from north, 49 out of 50 specimens collected during this study are from the northernmost part of Norway, Troms and Finnmark.

Diagnosis: See comparisons between $C$. norroenii and C. minuta under $C$. chalcographii. 
Type: Norway, Karasjok, from Ips acuminatus infesting Pinus sylvestris, 21 Jun. 2015, H. Solheim (O-F-259426 - holotype; CBS 147956 = CMW 57283 - extype culture).

Description: Sexual morph: not observed.

Asexual morphs: hyalorhinocladiella-like.

Hyalorhinocladiella-like morph: conidiophores micronematous or macronematous. The micronematous conidiophores, arising from vegetative hyphae, simple or branched (1 branches), hyaline, upright, straight or undulate, producing conidiogenous cells at their apices $(1.4-) 12.1-28.1(-33.3) \times(0.9-) 1.2-1.7(-2.1)$ $\mu \mathrm{m}$, often conidia formed singly, either directly on the side of vegetative hyphae or on short lateral branches. The macronematous conidiophores, hyaline, (9.3-)29.6-48.2(-64.9) long, and (8.5-)11.2-19.4(-15.8) $\mu \mathrm{m}$ wide at the apex, arising from a basal cell, (4.3-)6.2-11.7(-16) $\times(1.4-) 1.7-2.6(-3.1) \mu m$. The basal cells branch irregularly or penicillate and form 1-2 branches producing conidiogenous cells at their apices, 3-4 per branch. Conidiogenous cells integrated, hyaline, blastic, sometimes denticulate. Conidia hyaline, smooth, unicellular, oblong, sometimes slightly obovoid (2.7-)3.2-4.1(-5.1) × (1.1-)1.21.6(-2.3) $\mu \mathrm{m}$, no sheath.

Cultures: Colonies with optimal growth at $25^{\circ} \mathrm{C}$ on $2 \%$ MEA with radial growth rate $1.11( \pm 0.15) \mathrm{mm} / \mathrm{d}$. Colonies orange white, margin smooth, with suede-like surface, but occasionally funiculose. Hyphae hyaline, reverse pale orange (Kornerup and Wanscher 1978), smooth, submerged in the medium and aerial mycelium rarely, not constricted at the septa, 0.5-1.8 (mean 1 \pm 0.3$) \mu \mathrm{m}$ diam., asexual morph very abundant.

Ecology: Isolated from Ips acuminatus and Pityogenes quadridens infesting Pinus sylvestris.

Habitat. Pinus sylvestris forests.

Distribution: Currently only known from Norway.

Notes: See comparisons between $C$. norroenii and $C$. minuta under $C$. chalcographii. Ceratocystiopsis norroenii was commonly isolated from Ips acuminatus and Pityogenes quadridens infesting Scots pine growing in the north part of Norway.

Additional specimen examined: Norway: Målselv, from Ips acuminatus infesting Pinus sylvestris, 21 Jun. 2015, H. Solheim (O-F-259427, culture CBS 147957 = CMW 57284).

Ceratocystiopsis debeeria Jankowiak \& H. Solheim, sp. nov.

MycoBank: 841846

(Fig. 10).

Etymology: Named for Prof. Wilhelm de Beer who has contributed greatly to the fungal taxonomy of ophiostomatoid species.

Diagnosis: Ceratocystiopsis debeeria is the closest phylogenetic relative to $C$. neglecta. It can be differentiated from $C$. neglecta by the absence of perithecia and producing simple or very slightly irregularly branched conidiophores. Ceratocystiopsis neglecta produces simple or strongly penicilliaty branched conidiophores (Kirschner and Oberwinkler 1999). Morphologically, these two species also differ by the size of their conidia ranging from 3-4.5 $\mathrm{x} 1-1.5 \mu \mathrm{m}$ in C. neglecta (Kirschner and Oberwinkler 1999) vs. 2.7-5.2 × 0.9-1.7 $\mu \mathrm{m}$ in C. debeeria.

Type: Norway, Flesberg, from Pityogenes chalcographus infesting Picea abies, 31. Oct. 2014, M.E. Waalberg and R.A. Lindseth (0-F-259428 - holotype; CBS 147958 = CMW $57288-$ ex-type culture).

Description: Sexual morph: not observed.

Asexual morphs: hyalorhinocladiella-like.

Hyalorhinocladiella-like morph: conidiophores mononematous, micronematous, arising from vegetative hyphae, simple or slightly and irregularly branched, upright, straight or undulate, producing conidiogenous cells at their apices, (7.8-)10.6-25.8(-37.9) × $(0.8-) 1-1.4(-1.8) \mu \mathrm{m}$. Conidiogenous cells integrated, hyaline, blastic, rarely denticulate. Conidia hyaline, aseptate, obovoid with the upper part swollen, apex round, tapering toward base, sometimes oblong, no sheath, (2.7-)3.1-4.2(-5.2) × (0.9-)1.1-1.4(-1.7) $\mu \mathrm{m}$.

Cultures: Colonies with optimal growth at $25^{\circ} \mathrm{C}$ on $2 \%$ MEA with radial growth rate $0.82( \pm 0.18) \mathrm{mm} / \mathrm{d}$. Colonies yellowish white, margin smooth, with suedelike surface. Hyphae hyaline to pale grey in colour, reverse pale orange (Kornerup and Wanscher 1978), smooth, submerged in the medium and aerial mycelium rarely, not constricted at the septa, 0.8-2.9 (mean 1.6 \pm 0.4$) \mu \mathrm{m}$ diam., asexual morph very abundant.

Ecology: Isolated from Pityogenes chalcographus infesting Picea abies and Pinus sylvestris.

Habitat. Picea abies and Pinus sylvestris forests.

Distribution: Currently only known from Norway.

Notes: In a phylogenetic perspective, $C$. debeeria is closely related to $C$. neglecta (Figs. 2-4). Ceratocystiopsis debeeria is characterized by the absence of perithecia, which are present in $C$. neglecta (Kirschner and Oberwinkler 1999). In addition, C. debeeria can be distinguished from $C$. neglecta by the size of 
conidia.

Ceratocystiopsis debeeria was only isolated on a few occasions from Pityogenes chalcographus infesting Picea abies in Rendalen and Pinus sylvestris in Flesberg.

Additional specimen examined: Norway, Rendalen, from Pityogenes chalcographus infesting Pinus sylvestris, 29 Oct. 2014, H. Solheim (O-F-259429, culture CBS $147959=$ CMW57290).

Ceratocystiopsis troendelagii Jankowiak \& H. Solheim, sp. nov.

MycoBank: 841847

(Fig. 11)

Etymology. The epithet trendelagii (Latin) refers to the area in mid-Norway, Trøndelag, from which this fungus was collected.

Type: Norway, Lierne, from Polygraphus subopacus infesting Picea abies, 8 Aug. 2015, T. Kvamme and Å. Lindelöv (O-F-259430 - holotype; CBS 147962 = CMW57294 ex-type culture).

Diagnosis: The species is characterized by perithecia and a hyalorhinocladiella-like morph. It can be differentiated from the closely related species $C$. minima by smaller perithecial base diameter 25-54 $\mu \mathrm{m}$ vs. $40-85 \mu \mathrm{m}$ (Olchowecki and Reid 1974). Also $C$. troendelagii has shorter conidia ( $2.7-5.2 \mu \mathrm{m})$ compared to C. minima (2.5-8.0) $\mu \mathrm{m}$ (Olchowecki and Reid 1974). In addition, the conidia of $C$. minima are clavate or oblong while $C$. troendelagii has mainly obovoid conidia.

Description: Sexual morph perithecial. Perithecia abundantly produced on media and sterilized spruce twigs, bases black, globose or sub-globose (25-)33$45(-54) \mu \mathrm{m}$ diam. Necks black, straight or slightly curved, variable in length, (9-)11-29(-72) $\mu \mathrm{m}$ long. Diameter of the necks (4-)4.7-7.7(-10.7) $\mu \mathrm{m}$ at the apex and (12.5-)14.9-20.1(24.6) $\mu \mathrm{m}$ at the base. Ostiolar hyphae present, hyaline, aseptate, straight, tapering extensively towards the apex, 3-6 in number, (3.9-)7.2-10.5(-11.8) $\mathrm{mm}$ long. Asci not observed. Ascospores one-celled, hyaline, including the sheath falcate in side view (7-)8.8-11.8($13.5) \times(0.7-) 0.8-1.1(-1.3) \mu \mathrm{m}$, accumulated in a white-coloured mass at the tip of the neck.

Asexual morphs: hyalorhinocladiella-like.

Hyalorhinocladiella-like morph: conidiophores micronematous or macronematous. The micronematous conidiophores, arising from vegetative hyphae, simple, hyaline, upright, straight or undulate, producing conidiogenous cells at their apices $(5.9-) 8.7-20.4(-30.4) \times(0.8-) 1.3-2.2(-2.7) \mu \mathrm{m}$. The macronematous conidiophores, hyaline, (17.8-)21.9-34.8(-41.2) long, and (4.4-)11.7-28.8(-37.7) $\mu \mathrm{m}$ wide at the apex, arising from a basal cell, (3.5-)5.1-10.9(-16.5) $\times$ (1.7-)2.2-3.3(-4.1) $\mu \mathrm{m}$. The basal cells branch irregularly and form 2-3 branches producing conidiogenous cells at their apices, $2-4$ per branch. Conidiogenous cells integrated, hyaline, blastic, sometimes denticulate. Conidia hyaline, smooth, unicellular, oblong or obovate (2-)2.6-3.5(-4.1) $\times$ $(0.8-) 1.1-1.8(-2.2) \mu \mathrm{m}$, no sheath.

Cultures: Colonies with optimal growth at $20^{\circ} \mathrm{C}$ on $2 \%$ MEA with radial growth rate $0.72( \pm 0.05) \mathrm{mm} / \mathrm{d}$. Colonies yellowish white, margin smooth, with suedelike surface, but occasionally funiculose. Hyphae hyaline, reverse pale orange (Kornerup and Wanscher 1978), smooth, submerged in the medium and aerial mycelium rarely, not constricted at the septa, 0.7-2.2 (mean 1.2 \pm 0.4$) \mu \mathrm{m}$ diam., asexual morph very abundant.

Ecology. Isolated from Pityogenes saalasi and Polygraphus subopacus infesting Picea abies and Pinus sylvestris

Habitat. Picea abies and Pinus sylvestris forests

Distribution: Currently only known from Norway.

Notes: Ceratocystiopsis troendelagii is phylogenetically close to $C$. minima but formed a distinct clade in both the ITS1-5.8S-ITS2 and ITS2-28S trees as well in the $\beta$ T based tree (Figs. 2-4). It can be differentiated from C. minima by dimension of the perithecial base as well as morphology of conidia.

Ceratocystiopsis troendelagii was the rarest Ceratocystiopsis species isolated in this study. It was isolated twice in the same plot, once from Pityogenes saalasi and once from Polygraphus subopacus. Both bark beetles seem to have a northern distribution in Fennoscandia.

Additional specimen examined: Norway, Lierne, from Pityogenes saalasi infesting Picea abies, 8 Aug. 2015, T. Kvamme and Å. Lindelöv (0-F-259431, culture: CBS $147963=$ CMW57295) .

\section{Discussion}

In the present study, we collected 22 species of bark beetles from Picea abies and Pinus sylvestris located in Norway. From these beetles, we recovered 126 isolates that based on morphology showed affinities towards the genus Ceratocystiopsis. Analyses of molecular and morphological data indicated that four out of the six Ceratocystiopsis species recovered in this study were previously undescribed. Herein, we described these new species as $C$. chalcographii, $C$. debeeria, $C$. norroenii and $C$. troendelagii. Description of these new species brings the total number of recognized species in this genus to 24 , of which seven occur in Norway. These include the six species recovered in this study as well as $C$. minuta, which was previously found in association with $I$. typographus 
(Solheim 1986, 1992, 1993). In addition, C. rollhanseniana was described by Hausner et al. (2003) based on the Norwegian isolates collected by James Reid from P. sylvestris.

Ceratocystiopsis norroenii and C. rollhanseniana were the most frequently isolated Ceratocystiopsis species in this study. However, these species appear to have different distribution and insect associations. Ceratocystiopsis norroenii appears to be a consistent associate of Ips acuminatus on $P$. sylvestris while $C$. rollhanseniana has broader host/insect associations including different bark beetle species found on $P$. abies and $P$. sylvestris. Our phylogenetic analysis of the ITS2-28S sequences (Fig. 3) showed that some Polish isolates previously identified as $C$. minuta and collected from $P$. abies infested by I. typographus (CBS 116963, CBS 116796) actually represented C. rollhanseniana, showing its wider distribution in Europe.

Ceratocystiopsis norroenii belongs to the C. minuta s.l. grouping that includes several lineages from Europe and Japan (Plattner et al. 2009). According to Plattner et al. (2009) C. minuta contains different phylogenetic species, which are well-defined based on molecular and to some degree morphological criteria. Therefore, to stabilize the taxonomic position of $C$. minuta an epitype was designated for $C$. minuta based on the Polish strain RJ705=UAMH $11218=$ WIN(M) 1532 by Reid and Hausner (2010). The genetic linage of $C$. norroenii was not represented in Plattner et al.'s study (2009) suggesting that here are many C. minuta-like species that are morphologically similar. For example, $C$. weihaiensis a species from China was shown to be phylogenetically close to $C$. minuta (Chang et al. 2021).

In this study, besides $C$. norroenii we recovered eight other isolates that are part of the $C$. minuta s.l. species complex. These isolates were recovered from $P$. chalcographus on $P$. abies and represented a new species designated as $C$. chalcographii. The ITS1-5.8S-ITS2, ITS2-28S and $\beta$ T sequences of this taxon were identical or very close to several isolates from Scotland, Austria and Japan, which were identified previously as $C$. minuta. Therefore, $C$. chalcographii probably has a wider geographical distribution in Europe and Asia. More studies are needed on the taxonomic/genetic diversity of the $C$. minuta s.l. complex to resolve the various cryptic species that might be part of this group. In this study, $P$. chalcographus was also associated with $C$. debeeria. However, this fungus was found only in association with this beetle species, suggesting that $C$. debeeria is a specific ectosymbiont of $P$. chalcographii.

Ceratocystiopsis troendelagii and Ceratocystiopsis neglecta were found only on a few occasions in association with conifer-infesting bark beetles in Norway. Ceratocystiopsis troendelagii seems to be a fungal associate of $P$. saalasi and $P$. subopacus while $C$. neglecta was found associated with $H$. palliatus and $P$. subopacus. Ceratocystiopsis neglecta so far was only known from studies on different bark- and ambrosia beetles infesting coniferous trees in Germany (Kirschner 2001; Kirschner and Oberwinkler 1999). This is the first report of $C$. neglecta as a fungal associate of $P$. subopacus.

All of the species described in this study are morphologically similar, having a hyalorhinocladiella-like asexual states with hyaline conidia produced on nondenticulate conidiogenous cells. Ceratocystiopsis norroenii and $C$. troendelagii formed only simple conidiophores while $C$. chalcographii and $C$. troendelagii formed simple as well as condiophores with irregular branching patterns resembling loose structures. Where ascomata were present, these tended to have globose or elongated bases with short necks terminating in ostiolar hyphae and falcate acospores surrounded by hyaline sheaths. The newly described species demonstrated different optimal growth temperatures on $2 \%$ MEA. Ceratocystiopsis norroenii and C. debeeria grew optimally at $25{ }^{\circ} \mathrm{C}, \mathrm{C}$. chalcographii at $30{ }^{\circ} \mathrm{C}$, and $\mathrm{C}$. troendelagii at $20^{\circ} \mathrm{C}$. The four species described in this study can easily be distinguished from each other and from the other species of Ceratocystiopsis based on DNA sequence comparisons. Analyses of the ITS region sequence data were already sufficient to distinguish these species.

Most of the formally described species of Ceratocystiopsis are known only from conifers although $C$. lunata and $C$. synnemata were recently collected from hardwood-infesting beetles (Li et al. 2018; Strzałka et al. 2020; Nel 2021). The results of the present study confirm that in general there is a close affinity of Ceratocystiopsis species to conifers.

In this study, six species of Ceratocystiopsis were isolated from 22 species of bark beetles. Based on morphological characters and DNA sequence data, four new species of Ceratocystiopsis were described in addition this is the first report of $C$. neglecta for Norway. Although the relationships between fungi and bark beetles are relatively well recognized in Europe our survey led to the discovery and description of new species, suggesting that there are more novel fungal taxa to be discovered. The results of this study have substantially expanded our knowledge of Ceratocystiopsis species living in northern parts of Europe. Broadly, the results suggest that Ceratocystiopsis species are frequently occurring members of the Ophiostomatales in conifer ecosystems in Norway.

\section{Abbreviations}

BI: Bayesian Inference; $\beta$ T: $\beta$-tubulin; CAL: Calmodulin; CBS: Westerdijk Fungal Biodiversity Institute, Utrecht, The Netherlands; CMW: Culture Collection of the Forestry and Agricultural Biotechnology Institute (FABI), University of Pretoria, Pretoria, South Africa; ITS: The internal transcribed spacer; LSU: The large ribosomal subunit (28S); MEA: Malt extract agar; ML: Maximum likelihood; MP: Maximum Parsimony; NCBI: National Center for Biotechnology Information; NIBIO: Culture collection of Norwegian Institute of Bioeconomy, Norway; O: the Mycological Herbarium, Natural History Museum, University of Oslo, Norway; s.I: sensu lato; s.str: sensu stricto; TEF1-a: Translation elongation factor 1-a; UAMH: The UAMH centre for global microfungal biodiversity, Univeristy of Toronto, Canada; WIN(M or UM): Culture Collection of the University of Manitoba (Winnipeg); Canada.

\section{Declarations}

\section{Acknowledgements}

We would like to thank and acknowledge the following for their assistance across various aspects of this study. Terje B. Dahl, Torstein Kvamme, Geir Kvammen, Åke Lindelöv Ruben A. Lindseth, Tor H. Sundt, and Max E. Waalberg, for their assistance in field sampling. Anne E. Nielsen, Max E. Waalberg and Gro Wollebæk participated in laboratory work. T.K. helped with the identification of bark beetles. 
HS conceived the idea of this study, performed isolations and DNA sequencing, and edited the final version of the manuscript. RJ performed DNA sequencing, performed microscopy for the species descriptions and edited the description text, and wrote the manuscript. PB performed phylogenetic analysis. JM performed DNA sequencing, GH performed DNA sequencing and edited the final version of the manuscript.

\section{Funding}

This work was funded by the Norwegian biodiversity information centre on the project "Ophiostomatoid fungi in Norway" (No. 51-14) and Norwegian Institute of Bioeconomy Research, (No. 132001). This work was supported by the Ministry of Science and Higher Education of the Republic of Poland (SUB/040013/D019).

\section{Availability of data and materials}

All data generated or analysed during this study are included in this published article and/or is available from the corresponding author upon request.

\section{Ethics approval and consent to participate}

Not applicable.

\section{Adherence to national and international regulations}

Not applicable

\section{Consent for publication}

Not applicable

\section{Competing interests}

The authors declare that they have no competing interests.

\section{Author details}

${ }^{1}$ Department of Forest Ecosystems Protection; University of Agriculture in Krakow, Al. 29 Listopada 46, 31-425 Krakow, Poland

${ }^{2}$ Norwegian Institute of Bioeconomy Research, P.O. Box 115, 1431 Ås, Norway

${ }^{3}$ Department of Microbiology, Buller Building 213, University of Manitoba, Winnipeg, R3T 2N2, Canada

\section{References}

Aas T, Solheim H, Jankowiak R, Bilański P, Hausner G (2018) Four new Ophiostoma species associated with hardwood-infesting bark beetles in Norway and Poland. Fungal Biol 122:1142-1158. https://doi.org/10.1016/j.funbio.2018.08.001

Bridges JR, Perry TJ (1987) Ceratocystiopsis ranaculosus sp. nov. associated with the Southern Pine Beetle. Mycologia 79:630-633.

Carbone I, Kohn LM (1999) A method for designing primer sets for speciation studies filamentous ascomycetes. Mycologia 91:553-556. http://doi: $10.2307 / 3761358$

Chang R, Zhang X, Si H, Zhao G, Yuan X, Liu T, Bose T, Dai M (2021) Ophiostomatoid species associated with pine trees (Pinus spp.) infested by Cryphalus piceae from eastern China, including five new species. MycoKeys 83:181-208. https://doi.org/10.3897/mycokeys.83.70925

Darriba D, Taboada GL, Doallo R, Posada D (2012) jModelTest 2: more models, new heuristics and parallel computing. Nat Methods 9:772. https://doi: $10.1038 /$ nmeth. 2109

De Beer ZW, Wingfeld MJ (2013) Emerging lineages in the Ophiostomatales. In: Seifert KA, De Beer ZW, Wingfeld MJ (eds) The ophiostomatoid fungi: expanding frontiers. CBS biodiversity series, vol 12. CBS-KNAW Biodiversity Centre, Utrecht, The Netherlands, pp 21-46

De Beer ZW, Seifert KA, Wingfield MJ (2013a) A nomenclator for ophiostomatoid genera and species in the Ophiostomatales. In: Seifert KA, De Beer ZW, Wingfeld MJ (eds) The ophiostomatoid fungi: expanding frontiers. CBS Biodiversity Series, vol 12. CBS-KNAW Biodiversity Centre, Utrecht, The Netherlands, pp 245-322.

De Beer ZW, Seifert KA, Wingfeld MJ (2013b) The ophiostomatoid fungi: their dual position in the Sordariomycetes. In: Seifert KA, De Beer ZW, Wingfeld MJ (eds) The ophiostomatoid fungi: expanding frontiers. CBS Biodiversity Series, vol 12. CBS-KNAW Biodiversity Centre, Utrecht, The Netherlands, pp 1-19

De Beer ZW, Duong TA, Wingfield MJ (2016) The divorce of Sporothrix and Ophiostoma: solution to a problematic relationship. Stud Mycol 83:165191. https://doi. org/10.1016/j.simyco.2016.07.001 
Gardes M, Bruns TD (1993) ITS primers with enhanced specificity for Basidiomycetes - application to the identification of mycorrhiza and rusts. Mol Ecol 2:113-118.

Glass NL, Donaldson GC (1995) Development of primer sets designed for use with the PCR to amplify conserved genes from filamentous ascomycetes. Appl Environ Microb 61:1323-1330.

Griffin HD (1968) The genus Ceratocystis in Ontario. Can J Bot 46:689-718.

Grobbelaar J, De Beer ZW, Bloomer P, Wingfield MJ, Wingfield BD (2010) Ophiostoma tsotsi sp. nov., a wound-infesting fungus of hardwood trees in Africa. Mycopathologia 169:413-423. https://doi:10.1007/s11046-009-9267-8

Guindon S, Gascuel O (2003) A simple, fast and accurate method to estimate large phylogenies by maximum-likelihood. Syst Biol 52:696-704. https://doi: $10.1090 / 1063515150390235520$

Guindon S, Dufayard JF, Lefort V, Anisimova M, Hordijk W, Gascuel O (2010) New algorithms and methods to estimate maximum-likelihood phylogenies: assessing the performance of PhyML 3.0. Syst Biol 59:307-321. https://doi: 10.1093/sysbio/syq010

Hall TA (1999) BioEdit: a user-friendly biological sequence alignment editor and analysis program for Windows 95/98/NT. Nucleic Acids Symposium, Ser 41:95-98.

Hausner G, Reid J, Klassen GR (1993) The genus Ceratocystiopsis: a reappraisal based on molecular criteria. Mycol Res 97:625-633.

Hausner G, Eyjolfsdottir GG, Reid J (2003) Three new species of Ophiostoma and notes on Cornuvesica falcata. Can J Bot 81:40-48. https://doi.org/10.1139/b03-009

Hsiau PT-W, Harrington TC (1997) Ceratocystiopsis brevicomi sp. nov., a mycangial fungus from Dendroctonus brevicomis (Coleoptera: Scolytidae). Mycologia 89:661-669.

Hyde KD, Norphanphoun C, Maharachchikumbura SSN, Bhat DJ, Jones EBG, Bundhun D, Chen YJ, Bao DF, Boonmee S, Calabon MS, Chaiwan N, Chethana KWT, Dai DQ, Dayarathne MC, Devadatha B, Dissanayake AJ, Dissanayake LS, Doilom M, Dong W, Fan XL, Goonasekara ID, Hongsanan S, Huang SK, Jayawardena RS, Jeewon R, Karunarathna A, Konta S, Kumar V, Lin CG, Liu JK, Liu NG, Luangsa-ard J, Lumyong S, Luo ZL, Marasinghe DS, McKenzie EHC, Niego AGT, Niranjan M, Perera RH, Phukhamsakda C, Rathnayaka AR, Samarakoon MC, Samarakoon SMBC, Sarma VV, Senanayake IC, Shang QJ, Stadler M, Tibpromma S, Wanasinghe DN, Wei DP, Wijayawardene NN, Xiao YP, Yang J, Zeng XY, Zhang SN, Xiang MM (2020) Refined families of Sordariomycetes. Mycosphere 11(1):305-1059.

Jankowiak R (2005) Fungi associated with Ips typographus on Picea abies in Southern Poland and their succession into the phloem and sapwood of beetleinfested trees and logs. Forest Pathol 35:37-55.

Kamgan Nkuekam G, De Beer ZW, Wingfield MJ, Roux J (2011) A diverse assemblage of Ophiostoma species, including two new taxa on eucalypt trees in South Africa. Mycol Prog 11:515-533. https://doi.org/10.1007/s11557-011-0767-9

Katoh K, Standley DM (2013) MAFFT multiple sequence alignment software version 7, improvements in performance and usability. Mol Biol Evol 30:772780. https://doi.org/10.1093/molbev/mst010

Kirisits T (2004) Fungal associates of European bark beetles with special emphasis on the ophiostomatoid fungi. In: Lieutier F, Day KR, Battisti A, Gregoire JC, Evans $\mathrm{H}$ (eds.) Bark and Wood Boring Insects in Living Trees in Europe, A Synthesis. Kluwer, Dordrecht, pp. 185-223

Kirschner R (2001) Diversity of filamentous fungi in bark beetle galleries in central Europe. In: Misra JK, Horn BW (eds.) Trichomycetes and Other Fungal Groups. Trichomycetes and Other Fungal Groups. Robert W. Lichtwardt Commemoration Volume, pp 175-196

Kirschner R, Oberwinkler F (1999). A new Ophiostoma species associated with bark beetles infesting Norway spruce. Can J Bot 77:247-252.

Kornerup A, Wanscher JH (1978) Methuen Handbook of Colour. Third Edition. Eyre Methuen, London, 1-252.

Li Y, Huang Y-T, Kasson MT., Macias AM, Skelton J, Carlson PS, Yin M, Hulcr J (2018) Specific and promiscuous ophiostomatalean fungi associated with Platypodinae ambrosia beetles in the southeastern United States. Fungal Ecol 35:42-50.

Linnakoski R, de Beer ZW, Niemelä P, Wingfield MJ (2012) Associations of conifer-infesting bark beetles and fungi in Fennoscandia. Insects 3:200-227.

Marmolejo JG, Butin H (1990) New conifer-inhabiting species of Ophiostoma and Ceratocystiopsis (Ascomycetes, Microascales) from Mexico. Sydowia 42:193-199.

Nel WJ, Wingfield MJ, de Beer ZW, Duong TA (2021) Ophiostomatalean fungi associated with wood boring beetles in South Africa including two new species. Anton Leeuw 114(6):667-686. doi: 10.1007/s10482-021-01548-0

O’Donnell K, Cigelnik E (1997) Two divergent intragenomic rDNA ITS2 types within a monophyletic lineage of the fungus Fusarium are nonorthologous. Mol Biol Evol 7:103-116. https://doi.org/10.1006/mpev.1996.0376

Page $10 / 23$ 
O'Donnell K, Kistler HC, Cigelnik E, Ploetz RC (1998) Multiple evolutionary origins of the fungus causing Panama disease of banana: concordant evidence from nuclear and mitochondrial gene genealogies. P Natl Acad Sci USA 95:2044-2049. http://doi: 10.1073/pnas.95.5.2044

O'Donnell K, Nirenberg H, Aoki T, Cigelnik E (2000) A multigene phylogeny of the Gibberella fujikuroi species complex: detection of additional phylogenetically distinct species. Mycoscience 41:61-78. https://doi.org/10.1007/BF02464387

Olchowecki A, Reid J (1974) Taxonomy of the genus Ceratocystis in Manitoba. Can J Bot 52:1675-1711.

Plattner A, Kim J-J, Reid J, Hausner G, Lim YW, Yamaoka Y, Breuil C (2009) Resolving taxonomic and phylogenetic incongruence within species Ceratocystiopsis minuta. Mycologia 101:878-887. doi:10.3852/08-132

Rambaut A, Drummond AJ (2007) Tracer v1.4, Available from http://beast.bio.ed.ac.uk/Tracer

Robert V, Vu D, Amor AB, Van de Wiele N, Brouwer C, et al (2013) MycoBank gearing up for new horizons. IMA Fungus 4:371379. https://doi.org/10.5598/imafungus.2013.04.02.16

Reid J, Hausner G (2010) The epitypification of Ophiostoma minutum, now Ceratocystiopsis minuta. Mycotaxon 113:463-474. doi:https://doi.org/10.5248/113.463

Ronquist F, Huelsenbeck JP (2003) MrBayes 3: Bayesian phylogenetic inference under mixed models. Bioinformatics 19:15721574. https://doi.org/10.1093/sysbio/sys029

Siemaszko W (1939) Zespoły grzybów towarzyszących kornikom polskim. Planta Pol. 7:1-54.

Solheim H (1986) Species of Ophiostomataceae isolated from Picea abies infested by the bark beetle Ips typographus. Nord J Bot 6:199-207.

Solheim H (1992) Fungal succession in sapwood of Norway spruce infested by the bark beetle Ips typographus. Eur J For Pathol 22:136-48.

Solheim H (1993) Fungi associated with the spruce bark beetle Ips typographus in an endemic area in Norway. Scand J For Res 8:118-22.

Strzałka B, Jankowiak R, Bilański P, Patel N, Hausner G, Linnakoski R, Solheim H (2020) Two new species of Ophiostomatales (Sordariomycetes) associated with the bark beetle Dryocoetes alni from Poland. MycoKeys 68:23-48.

Swofford DL (2003) PAUP* 4.0: phylogenetic analysis using parsimony (*and other methods). Sinauer Associates, Sunderland, Massachusetts.

Upadhyay HP (1981) A monograph of Ceratocystis and Ceratocystiopsis. Athens: The University of Georgia Press.

Upadhyay HP, Kendrick WB (1975) Prodromous for a revision of Ceratocystis (Microascales, Ascomycetes) and its conidial states. Mycologia 67:798-805.

Viljoen CD, Wingfield MJ, Jacobs K, Wingfield BD (2000) Cornuvesica, a new genus to accommodate Ceratocystiopsis falcate. Mycol Res 104(3):365-367.

Wang Z, Liu Y, Wang H, Meng X, Liu X, Decock C, Zhang X, Lu Q (2020) Ophiostomatoid fungi associated with Ips subelongatus, including eight new species from northeastern China. IMA Fungus 11:3. doi:10.1186/s43008-019-0025-3

White T, Bruns T, Lee S, Taylor J (1990) Amplification and direct sequencing of fungal ribosomal RNA genes for phylogenetics. In: Innis MA, Gelfand DH, Snisky JJ, White TJ (eds) PCR protocols: a guide to methods and applications. Academic Press, New York, pp 315-322. https://doi.org/10.1016/B978-0-12372180-8.50042-1

Yamaoka Y, Wingfield MJ, Takahashi I, Solheim H (1997) Ophiostomatoid fungi associated with the spruce bark beetle Ips typographus $f$. japonicus in Japan. Mycol Res 101:1215-1227 http://dx.doi.org/10.1017/S0953756297003924.

Zipfel RD, de Beer ZW, Jacobs K, Wingfield BD, Wingfield MJ (2006) Multi-gene phylogenies define Ceratocystiopsis and Grosmannia distinct from Ophiostoma. Stud Mycol 55:75-97. doi: 10.3114/sim.55.1.75.

\section{Tables}

Table 1 Bark beetle sampling sites

Picea abies (Pa), Pinus sylvestris (Ps)

Table 2 Isolates used in the present study 


\begin{tabular}{|c|c|c|c|c|c|c|}
\hline Sampling site & Latitude & Longitude & Municipality & County & Bark beetle species & Host \\
\hline 1 & 69.818212 & 25.157902 & Porsanger & Finnmark & P. quadridens & Ps \\
\hline 2 & 69.551479 & 25.831215 & Karasjok 4 & Finnmark & I. acuminatus / P. bidentatus & Ps \\
\hline 3 & 69.465227 & 25.568562 & Karasjok 6 & Finnmark & P. quadridens / P. bidentatus & Ps \\
\hline 4 & 69.060888 & 18.995351 & Målselv 5 & Troms & I. acuminatus & Ps \\
\hline 5 & 69.001709 & 18.995351 & Målselv 6 & Troms & I. acuminatus & Ps \\
\hline 6 & 64.403248 & 13.548321 & Lierne & Trøndelag & P. saalasi / P. subopacus & $\mathrm{Pa}$ \\
\hline 7 & 61.728590 & 11.344890 & Rendalen & Innlandet & P. chalcographus & Ps \\
\hline 8 & 60.373333 & 12.461444 & Grue & Innlandet & P. quadridens & Ps \\
\hline 9 & 60.237895 & 10.986056 & Nannestad & Viken & P. poligraphus / P. chalcographus & $\mathrm{Pa}$ \\
\hline 10 & 59.668680 & 10.718710 & Ås & Viken & H. palliatus & $\mathrm{Pa}$ \\
\hline 11 & 59.639736 & 10.654259 & Frogn1 & Viken & C. pusillus / O. proximus & Ps \\
\hline 12 & 59.634348 & 10.668942 & Frogn 2 & Viken & C. cinereus / O. proximus & Ps \\
\hline 13 & 59.743666 & 9.564444 & Flesberg & Viken & P. chalcographus & Ps \\
\hline
\end{tabular}




\begin{tabular}{|c|c|c|c|c|c|c|c|c|}
\hline \multirow[t]{2}{*}{ Fungal species } & \multicolumn{3}{|c|}{ Isolate no. ${ }^{1}$} & \multirow[t]{2}{*}{ Tree host } & \multirow[t]{2}{*}{ Insect vector } & \multirow[t]{2}{*}{ Site $^{2}$} & \multicolumn{2}{|c|}{ GenBank accession } \\
\hline & CBS & $\mathrm{CMW}$ & NIBO or WIN ${ }^{C}$ & & & & ITS & LSU \\
\hline $\begin{array}{l}\text { Ceratocystiopsis chalcographii sp. } \\
\text { nov. }\end{array}$ & $147954^{\top}$ & 57280 & N2015-0121/2 & $\begin{array}{l}\text { Picea } \\
\text { abies }\end{array}$ & $\begin{array}{l}\text { Pityogenes } \\
\text { chalcographus }\end{array}$ & Nannestad & OL309930 & OL30 \\
\hline \multirow[t]{7}{*}{ Taxon 1} & & 57281 & N2015-0132/2/3 & $\begin{array}{l}\text { Picea } \\
\text { abies }\end{array}$ & $\begin{array}{l}\text { Pityogenes } \\
\text { chalcographus }\end{array}$ & Nannestad & OL309931 & OL30 \\
\hline & 147953 & 57279 & N2015-0158/3/3 & $\begin{array}{l}\text { Pinus } \\
\text { sylvestris }\end{array}$ & $\begin{array}{l}\text { Pityogenes } \\
\text { chalcographus }\end{array}$ & Rendalen & OL309932 & OL3C \\
\hline & $147955^{\mathrm{A}}$ & 57282 & N2015-0167/2/1 & $\begin{array}{l}\text { Pinus } \\
\text { sylvestris }\end{array}$ & $\begin{array}{l}\text { Pityogenes } \\
\text { chalcographus }\end{array}$ & Rendalen & OL309933 & OL3O \\
\hline & & & N2015-0123/3/3 & $\begin{array}{l}\text { Picea } \\
\text { abies }\end{array}$ & $\begin{array}{l}\text { Pityogenes } \\
\text { chalcographus }\end{array}$ & Nannestad & - & - \\
\hline & & & N2015-0134/2 & $\begin{array}{l}\text { Picea } \\
\text { abies }\end{array}$ & $\begin{array}{l}\text { Pityogenes } \\
\text { chalcographus }\end{array}$ & Nannestad & - & - \\
\hline & & & N2015-0171/1/4 & $\begin{array}{l}\text { Pinus } \\
\text { sylvestris }\end{array}$ & $\begin{array}{l}\text { Pityogenes } \\
\text { chalcographus }\end{array}$ & Rendalen & - & - \\
\hline & & & N2015-0174/2/1 & $\begin{array}{l}\text { Pinus } \\
\text { sylvestris }\end{array}$ & $\begin{array}{l}\text { Pityogenes } \\
\text { chalcographus }\end{array}$ & Rendalen & - & - \\
\hline Ceratocystiopsis norroenii sp. nov. & & 57285 & N2015-0494/1/2 & $\begin{array}{l}\text { Pinus } \\
\text { sylvestris }\end{array}$ & Ips acuminatus & Målselv 5 & OL309934 & OL3O \\
\hline \multirow[t]{8}{*}{ Taxon 2} & & 57287 & N2015-0528/2/3 & $\begin{array}{l}\text { Pinus } \\
\text { sylvestris }\end{array}$ & Ips acuminatus & Målselv 6 & OL309935 & OL3O \\
\hline & $147956^{\top}$ & 57283 & N2015-0537/2/3 & $\begin{array}{l}\text { Pinus } \\
\text { sylvestris }\end{array}$ & Ips acuminatus & Karasjok 6 & OL309936 & OL3O \\
\hline & & 57286 & N2015-0545/2/4 & $\begin{array}{l}\text { Pinus } \\
\text { sylvestris }\end{array}$ & Ips acuminatus & Karasjok 6 & OL309937 & OL3O \\
\hline & $147957^{A}$ & 57284 & N2015-0526/2/3 & $\begin{array}{l}\text { Pinus } \\
\text { sylvestris }\end{array}$ & Ips acuminatus & Målselv 6 & OL309938 & OL3C \\
\hline & & & N2015-0032/2/2 & $\begin{array}{l}\text { Pinus } \\
\text { sylvestris }\end{array}$ & $\begin{array}{l}\text { Pityogenes } \\
\text { quadridens }\end{array}$ & Frogn 2 & - & - \\
\hline & & & N2015-0503/1/4/1 & $\begin{array}{l}\text { Pinus } \\
\text { sylvestris }\end{array}$ & Ips acuminatus & Målselv 5 & - & - \\
\hline & & & N2015-0523/2/3 & $\begin{array}{l}\text { Pinus } \\
\text { sylvestris }\end{array}$ & Ips acuminatus & Målselv 6 & - & - \\
\hline & & & N2015-0842/2/5 & $\begin{array}{l}\text { Pinus } \\
\text { sylvestris }\end{array}$ & $\begin{array}{l}\text { Pityogenes } \\
\text { quadridens }\end{array}$ & Porsanger & - & - \\
\hline Ceratocystiopsis debeeria sp. nov. & $147959^{A}$ & 57290 & N2015-0165/1/3/1 & $\begin{array}{l}\text { Pinus } \\
\text { sylvestris }\end{array}$ & $\begin{array}{l}\text { Pityogenes } \\
\text { chalcographus }\end{array}$ & Rendalen & OL309939 & OL3O \\
\hline \multirow[t]{3}{*}{ Taxon 3} & & 57289 & N2015-0176/3/3/1 & $\begin{array}{l}\text { Pinus } \\
\text { sylvestris }\end{array}$ & $\begin{array}{l}\text { Pityogenes } \\
\text { chalcographus }\end{array}$ & Rendalen & OL309940 & OL3O \\
\hline & & 57291 & N2015-0177/1/2 & $\begin{array}{l}\text { Picea } \\
\text { abies }\end{array}$ & $\begin{array}{l}\text { Pityogenes } \\
\text { chalcographus }\end{array}$ & Flesberg & OL309941 & OL30 \\
\hline & $147958^{\top}$ & 57288 & N2015-0179/5/2 & $\begin{array}{l}\text { Picea } \\
\text { abies }\end{array}$ & $\begin{array}{l}\text { Pityogenes } \\
\text { chalcographus }\end{array}$ & Flesberg & OL309942 & OL3C \\
\hline $\begin{array}{l}\text { Ceratocystiopsis troendelagii sp. } \\
\text { nov. }\end{array}$ & $147962^{\top}$ & 57294 & N2015-0879/2/5 & $\begin{array}{l}\text { Picea } \\
\text { abies }\end{array}$ & $\begin{array}{l}\text { Polygraphus } \\
\text { subopacus }\end{array}$ & Lierne & OL309943 & OL3C \\
\hline Taxon 4 & $147963^{A}$ & 57295 & N2015-0918/2/4 & $\begin{array}{l}\text { Picea } \\
\text { abies }\end{array}$ & $\begin{array}{l}\text { Pityogenes } \\
\text { saalasi }\end{array}$ & Lierne & OL309944 & OL3C \\
\hline Ceratocystiopsis neglecta & 147960 & 57292 & N2015-0445/3/4 & $\begin{array}{l}\text { Picea } \\
\text { abies }\end{array}$ & $\begin{array}{l}\text { Hylurgops } \\
\text { palliatus }\end{array}$ & Ås & OL309945 & OL3C \\
\hline \multirow[t]{4}{*}{ Taxon 5} & & & N2015-0888/3/1 & $\begin{array}{l}\text { Picea } \\
\text { abies }\end{array}$ & $\begin{array}{l}\text { Polygraphus } \\
\text { subopacus }\end{array}$ & Lierne & OL309946 & OL3C \\
\hline & 147961 & 57293 & N2015-0438/1/3 & $\begin{array}{l}\text { Picea } \\
\text { abies }\end{array}$ & $\begin{array}{l}\text { Hylurgops } \\
\text { palliatus }\end{array}$ & Ås & - & - \\
\hline & & & N2015-0439/1/3 & $\begin{array}{l}\text { Picea } \\
\text { abies }\end{array}$ & $\begin{array}{l}\text { Hylurgops } \\
\text { palliatus }\end{array}$ & Ås & - & OL3C \\
\hline & $100596^{\top}$ & & & $\begin{array}{l}\text { Picea } \\
\text { abies }\end{array}$ & $\begin{array}{l}\text { Hylurgops } \\
\text { palliatus }\end{array}$ & $\begin{array}{l}\text { Baden- } \\
\text { Württemberg }\end{array}$ & MH862711 & MH8: \\
\hline
\end{tabular}




\begin{tabular}{|c|c|c|c|c|c|c|c|c|}
\hline Ceratocystiopsis rollhanseniana & 147950 & 57276 & N2015-0837/2/2 & $\begin{array}{l}\text { Pinus } \\
\text { sylvestris }\end{array}$ & $\begin{array}{l}\text { Pityogenes } \\
\text { quadridens }\end{array}$ & Porsanger & - & OL3C \\
\hline \multirow[t]{20}{*}{ Taxon 6} & 147952 & 57278 & N2015-0850/3/1 & $\begin{array}{l}\text { Pinus } \\
\text { sylvestris }\end{array}$ & $\begin{array}{l}\text { Pityogenes } \\
\text { bidentatus }\end{array}$ & Karasjok 4 & - & OL30 \\
\hline & 147951 & 57277 & N2015-0946/3/2 & $\begin{array}{l}\text { Pinus } \\
\text { sylvestris }\end{array}$ & $\begin{array}{l}\text { Orthotomicus } \\
\text { proximus }\end{array}$ & Frogn 1 & - & OL30 \\
\hline & & & N2015-0946/3/1 & $\begin{array}{l}\text { Pinus } \\
\text { sylvestris }\end{array}$ & $\begin{array}{l}\text { Orthotomicus } \\
\text { proximus }\end{array}$ & Frogn 1 & - & OL3C \\
\hline & & & N2015-1162/2/2/1 & $\begin{array}{l}\text { Pinus } \\
\text { sylvestris }\end{array}$ & $\begin{array}{l}\text { Crypturgus } \\
\text { pusillus coll. }\end{array}$ & Frogn 1 & - & OL30 \\
\hline & & & N2015-1169/1/2/1 & $\begin{array}{l}\text { Pinus } \\
\text { sylvestris }\end{array}$ & $\begin{array}{l}\text { Crypturgus } \\
\text { pusillus coll. }\end{array}$ & Frogn 1 & - & OL30 \\
\hline & & & N2015-0003/2/3 & $\begin{array}{l}\text { Pinus } \\
\text { sylvestris }\end{array}$ & $\begin{array}{l}\text { Pityogenes } \\
\text { quadridens }\end{array}$ & Grue & - & - \\
\hline & & & N2015-0859/3/2 & $\begin{array}{l}\text { Pinus } \\
\text { sylvestris }\end{array}$ & $\begin{array}{l}\text { Pityogenes } \\
\text { bidentatus }\end{array}$ & Karasjok 4 & - & - \\
\hline & & & N2016-0836/3/4 & $\begin{array}{l}\text { Pinus } \\
\text { sylvestris }\end{array}$ & $\begin{array}{l}\text { Pityogenes } \\
\text { quadridens }\end{array}$ & Porsanger & - & - \\
\hline & & & N2015-0847/3/2 & $\begin{array}{l}\text { Pinus } \\
\text { sylvestris }\end{array}$ & $\begin{array}{l}\text { Pityogenes } \\
\text { quadridens }\end{array}$ & Karasjok 6 & - & - \\
\hline & & & N2015-0493/3/2 & $\begin{array}{l}\text { Pinus } \\
\text { sylvestris }\end{array}$ & Ips acuminatus & Målselv 5 & - & - \\
\hline & & & N2015-0846/2/4 & $\begin{array}{l}\text { Pinus } \\
\text { sylvestris }\end{array}$ & $\begin{array}{l}\text { Pityogenes } \\
\text { bidentatus }\end{array}$ & Karasjok 6 & - & - \\
\hline & & & N2015-0849/1/1 & $\begin{array}{l}\text { Pinus } \\
\text { sylvestris }\end{array}$ & $\begin{array}{l}\text { Pityogenes } \\
\text { bidentatus }\end{array}$ & Karasjok 6 & - & - \\
\hline & & & N2015-0855/3/2 & $\begin{array}{l}\text { Pinus } \\
\text { sylvestris }\end{array}$ & $\begin{array}{l}\text { Pityogenes } \\
\text { bidentatus }\end{array}$ & Karasjok 4 & - & - \\
\hline & & & N2015-0857/2/1 & $\begin{array}{l}\text { Pinus } \\
\text { sylvestris }\end{array}$ & $\begin{array}{l}\text { Pityogenes } \\
\text { bidentatus }\end{array}$ & Karasjok 4 & - & - \\
\hline & & & N2015-0857/3/1 & $\begin{array}{l}\text { Pinus } \\
\text { sylvestris }\end{array}$ & $\begin{array}{l}\text { Pityogenes } \\
\text { bidentatus }\end{array}$ & Karasjok 4 & - & - \\
\hline & & & N2015-0938/2/3 & $\begin{array}{l}\text { Pinus } \\
\text { sylvestris }\end{array}$ & $\begin{array}{l}\text { Orthotomicus } \\
\text { proximus }\end{array}$ & Frogn 1 & - & - \\
\hline & & & N2015-0947/1/2 & $\begin{array}{l}\text { Pinus } \\
\text { sylvestris }\end{array}$ & $\begin{array}{l}\text { Orthotomicus } \\
\text { proximus }\end{array}$ & Frogn 1 & - & OL30 \\
\hline & & & WIN110,UAMH9797 & $\begin{array}{l}\text { Pinus } \\
\text { sylvestris }\end{array}$ & $\begin{array}{l}\text { Bark beetle } \\
\text { galleries }\end{array}$ & Kongsvinger & EU913719 & EU91 \\
\hline & & & WIN113,UAMH9774 & $\begin{array}{l}\text { Pinus } \\
\text { sylvestris }\end{array}$ & $\begin{array}{l}\text { Bark beetle } \\
\text { galleries }\end{array}$ & Tangen & EU913718 & EU91 \\
\hline & & & WIN117 & $\begin{array}{l}\text { Pinus } \\
\text { sylvestris }\end{array}$ & $\begin{array}{l}\text { Bark beetle } \\
\text { galleries }\end{array}$ & Kongsvinger & - & - \\
\hline
\end{tabular}

${ }^{1}$ CBS Westerdijk Fungal Biodiversity Institute, Utrecht, The Netherlands; CMW Culture Collection of the Forestry and Agricultural Biotechnology Institute (FABI), University of Pretoria, Pretoria, South Africa; NIBO (N) Culture collection of Norwegian Institute of Bioeconomy (NIBIO), Norway; UAMH: The UAMH centre for global microfungal biodiversity, Univeristy of Toronto, Toronto, Canada; WIN Culture Collection of the University of Manitoba (Winnipeg), Canada.

${ }^{2}$ All isolates were collected in Norway except C. neglecta CBS 100596 which was collected in Germany.

${ }^{3}$ ITS = internal transcribed spacer regions 1 and 2 of the nuclear ribosomal DNA operon, including the 5.8S region; LSU = internal transcribed spacer region 2 and the $28 \mathrm{~S}$ large subunit of the nrDNA gene; $\beta T$ = Beta-tubulin; $C A L=$ Calmodulin; TEF1a = Translation elongation factor 1-alpha; $B$ old type = GenBank accession numbers of sequences obtained in the present study.

$\mathrm{T}=$ ex-holotype isolates

$A=$ additional specimen examined 
Table 3 Number and frequencies (\%)* of Ceratocystiopsis isolates and frequency of occurrence obtained from 22 bark beetle species during the course of this study.

Picea abies $(\mathrm{Pa})$

\begin{tabular}{|c|c|c|c|c|c|c|c|c|c|c|c|c|c|}
\hline & & PIcea ab & (Pa) & & & & & & & & & & \\
\hline & & & & & & Pinus sy & vestris ( $P$ & & & & & & \\
\hline Beetle species & & 1 & 2 & 3 & 4 & 5 & 6 & 7 & 8 & 9 & 10 & 11 ** & Total \\
\hline Fungus species & & & & & & & & & & & & & \\
\hline C. chalcographii & taxon 1 & & & & & $8(11 \%)$ & & & & & & & 8 \\
\hline C. norrenii & taxon 2 & & & & & & & $49(54 \%)$ & & & $1(11 \%)$ & & 50 \\
\hline C. deberia & taxon 3 & & & & & $7(9 \%)$ & & & & & & & 7 \\
\hline C. trendelagii & taxon 4 & & & $1(3 \%)$ & $1(3 \%)$ & & & & & & & & 2 \\
\hline C. neglecta & taxon 5 & & $3(3 \%)$ & & $1(3 \%)$ & & & & & & & & 4 \\
\hline C. rollhanseniana & $\operatorname{tax} 0 n$ & $12(40 \%)$ & & & & & $6(29 \%)$ & $1(11 \%)$ & $21(70 \%)$ & $13(72 \%)$ & $2(22 \%)$ & & 55 \\
\hline
\end{tabular}

*The frequency of occurrence was calculated according to the following formula: $F=(N S / N T s) \times 100$, where $F$ represents the frequency of occurrence (\%) of the fungus, NS represents the number of bbtles from which a particular fungus was isolated, and NTs represents the total number of beetles.

Bark beetle species: 1 = Crypturgus cinereus, 2 = Hylurgops palliatus, $3=$ Pityogenes saalasi; $4=$ Polygraphus subopacus, $5=$ Pityogenes chalcographus; $6=$ Crypturgus pusillus; $7=$ Ips acuminatus, $8=$ Orthotomicus proximus, $9=$ Pityogenes bidentatus, $10=$ Pityogenes quadridens.

** No Ceratocystiopsis species were detected in samples from Cryphalus saltuarius; Dryocoetes autographus; Dryocoetes hectographus; Hylastes cunicularis, Hylastes brunneus; Ips sexdentatus; Orthotomicus laricis; Orthtomicus suturalis; Pityophthorus micrographus; Polygreaphus poligraphus; Tomicus piniperda; Trypodendrus lineatum.

\section{Figures}

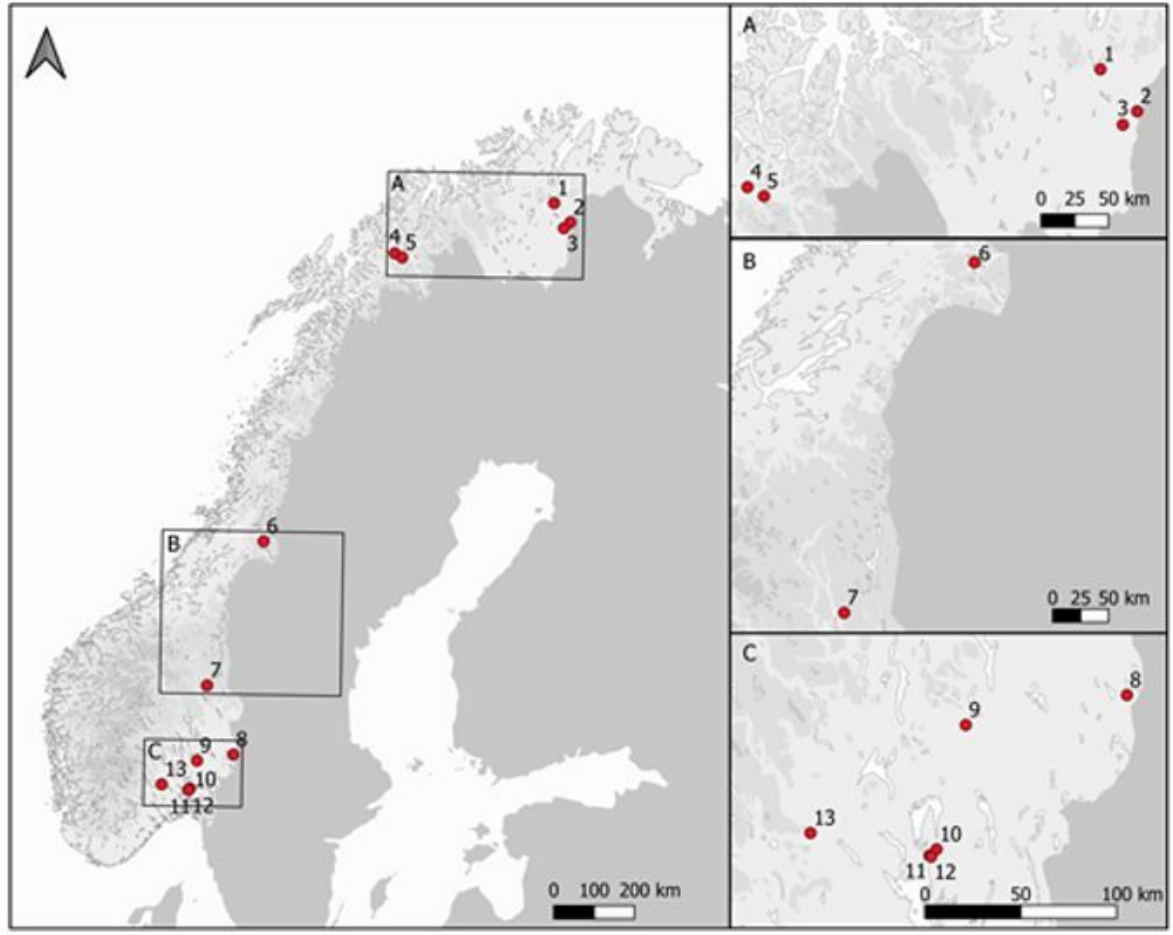

\section{Figure 1}

The sample sites in Norway where isolations from bark beetles yielded Ceratocystiopsis species. 


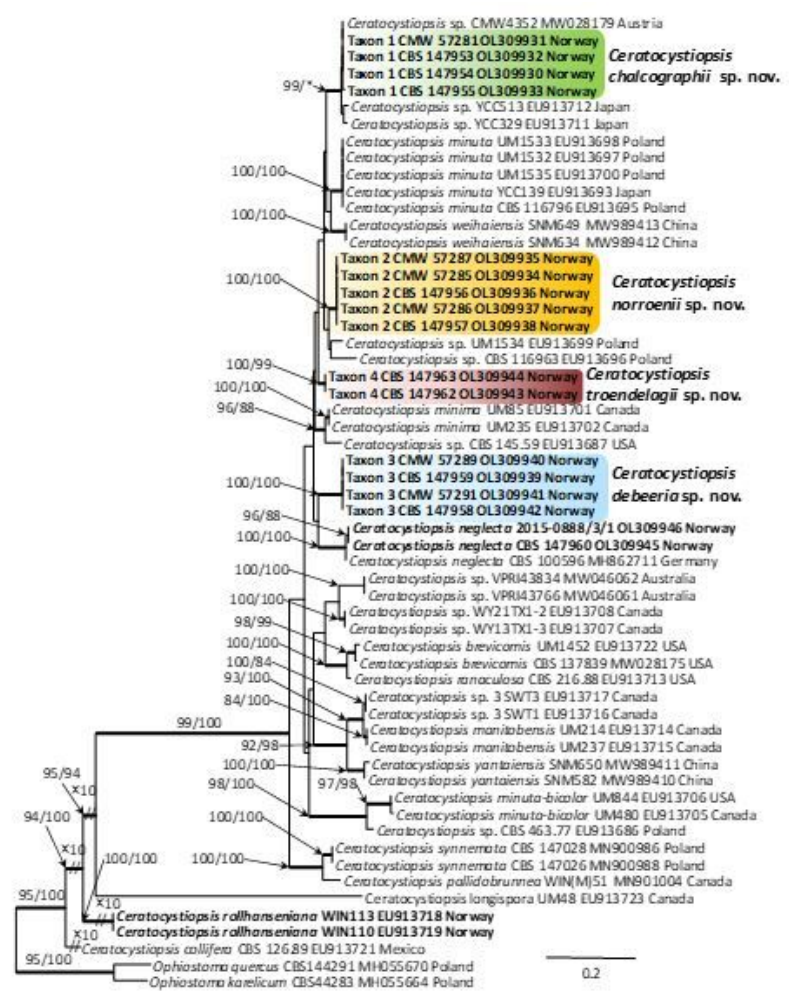

\section{Figure 2}

Phylogram obtained from Maximum Likelihood (ML) analyses of the ITS1-5.8S-ITS2-28S data for the Ceratocystiopsis spp. Sequences obtained during this study are presented in bold type. The Bootstrap values $\geq 75 \%$ for $\mathrm{ML}$ and Maximum Parsimony (MP) analyses are presented at nodes as follows: ML/MP. Bold branches indicate posterior probabilities values $\geq 0.95$ obtained from Bayesian Inference (BI) analyses. *Bootstrap values $<75 \%$. The tree is drawn to scale (see bar) with branch length measured in the number of substitutions per site. Ophiostoma karelicum and Ophiostoma quercus represent the outgroup.

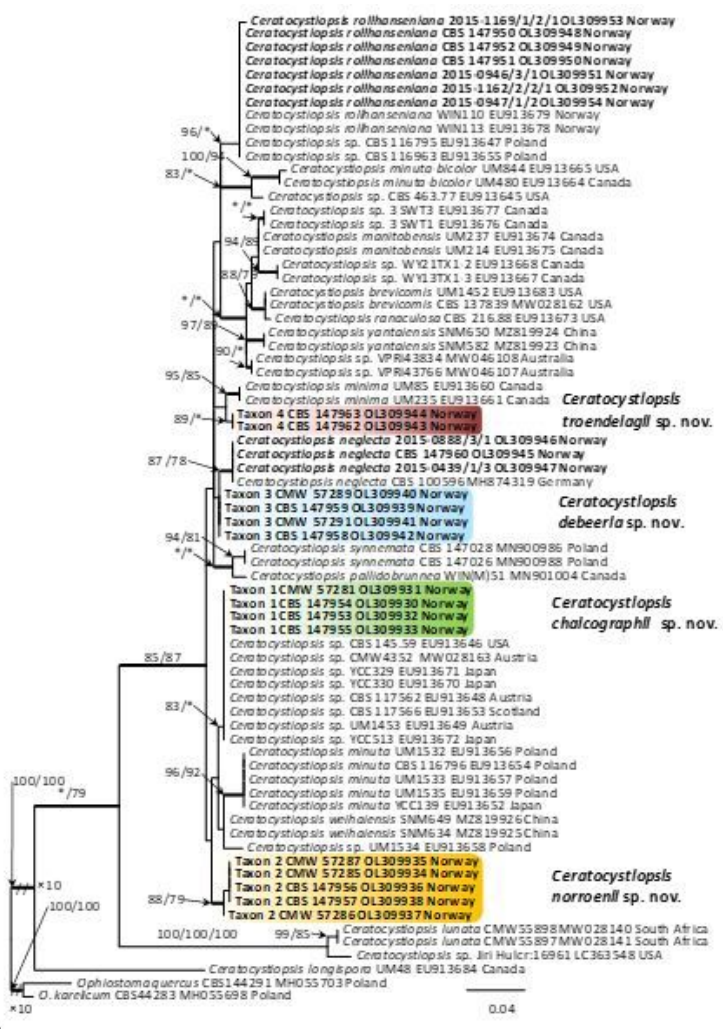

\section{Figure 3}

Phylogram obtained from Maximum Likelihood (ML) analyses of the ITS2-28S data for the Ceratocystiopsis spp. Sequences obtained during this study are presented in bold type. The Bootstrap values $\geq 75 \%$ for $\mathrm{ML}$ and Maximum Parsimony (MP) analyses are presented at nodes as follows: ML/MP. Bold 
branches indicate posterior probabilities values $\geq 0.95$ obtained from Bayesian Inference (BI) analyses. *Bootstrap values $<75 \%$. The tree is drawn to scale (see bar) with branch length measured in the number of substitutions per site. Ophiostoma karelicum and 0 . quercus represents the outgroup in analyses of ITS2-28S.

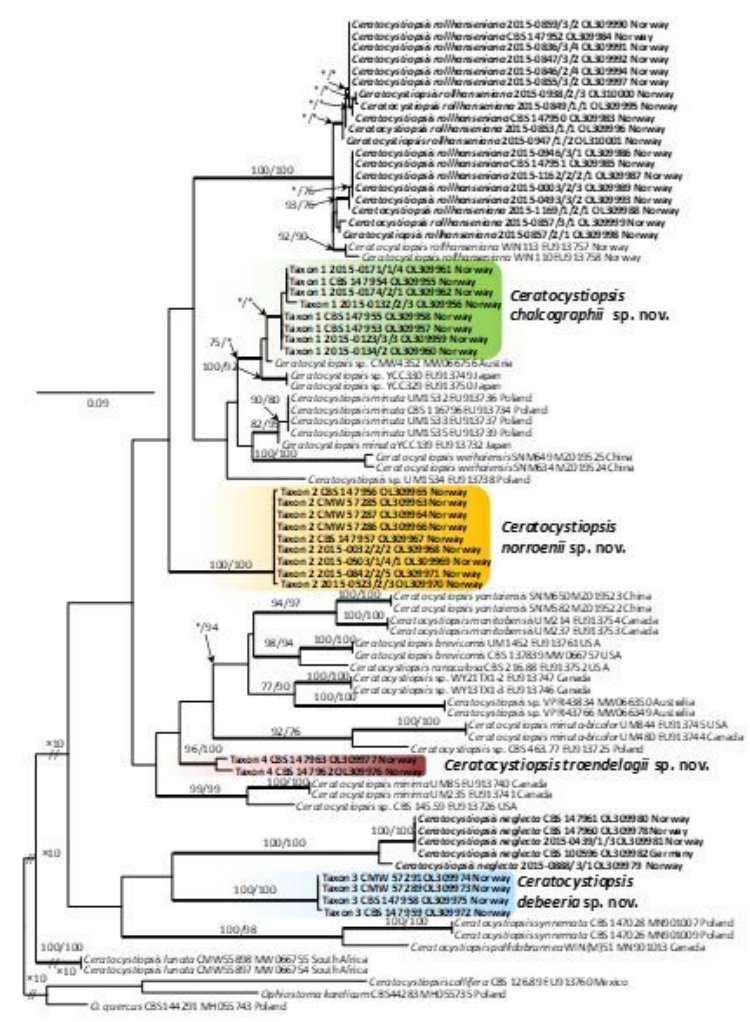

\section{Figure 4}

Phylogram obtained from Maximum Likelihood (ML) analyses of BT data for the Ceratocystiopsis spp. Sequences obtained during this study are presented in bold type. The Bootstrap values $\geq 75 \%$ for ML and Maximum Parsimony (MP) analyses are presented at nodes as follows: ML/MP. Bold branches indicate posterior probabilities values $\geq 0.95$ obtained from Bayesian Inference (BI) analyses. *Bootstrap values $<75 \%$. The tree is drawn to scale (see bar) with branch length measured in the number of substitutions per site. The tree is drawn to scale (see bar) with branch length measured in the number of substitutions per site. Ophiostoma karelicum and 0 . quercus represents the outgroup in analyses of ßT.

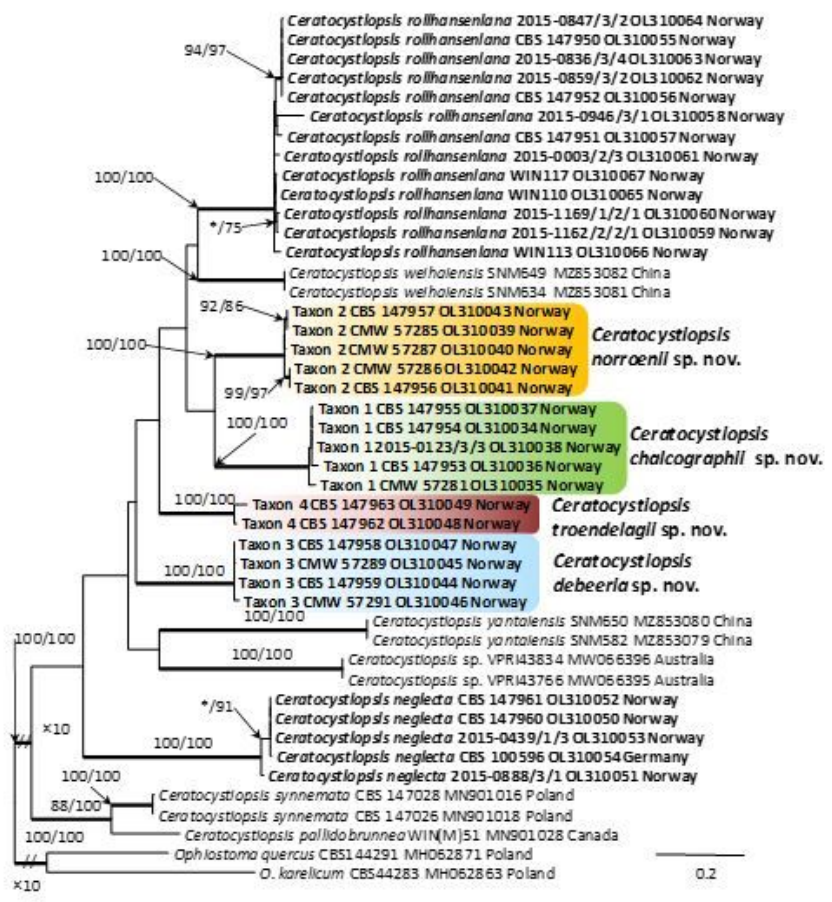

Figure 5 
Phylogram obtained from Maximum Likelihood (ML) analyses of TEF1-a data for the Ceratocystiopsis spp. Sequences obtained during this study are presented in bold type. The Bootstrap values $\geq 75 \%$ for ML and Maximum Parsimony (MP) analyses are presented at nodes as follows: ML/MP. Bold branches indicate posterior probabilities values $\geq 0.95$ obtained from Bayesian Inference (BI) analyses. *Bootstrap values $<75 \%$. The tree is drawn to scale (see bar) with branch length measured in the number of substitutions per site. Ophiostoma karelicum and 0 . quercus represents the outgroup in analyses of TEF1-a.

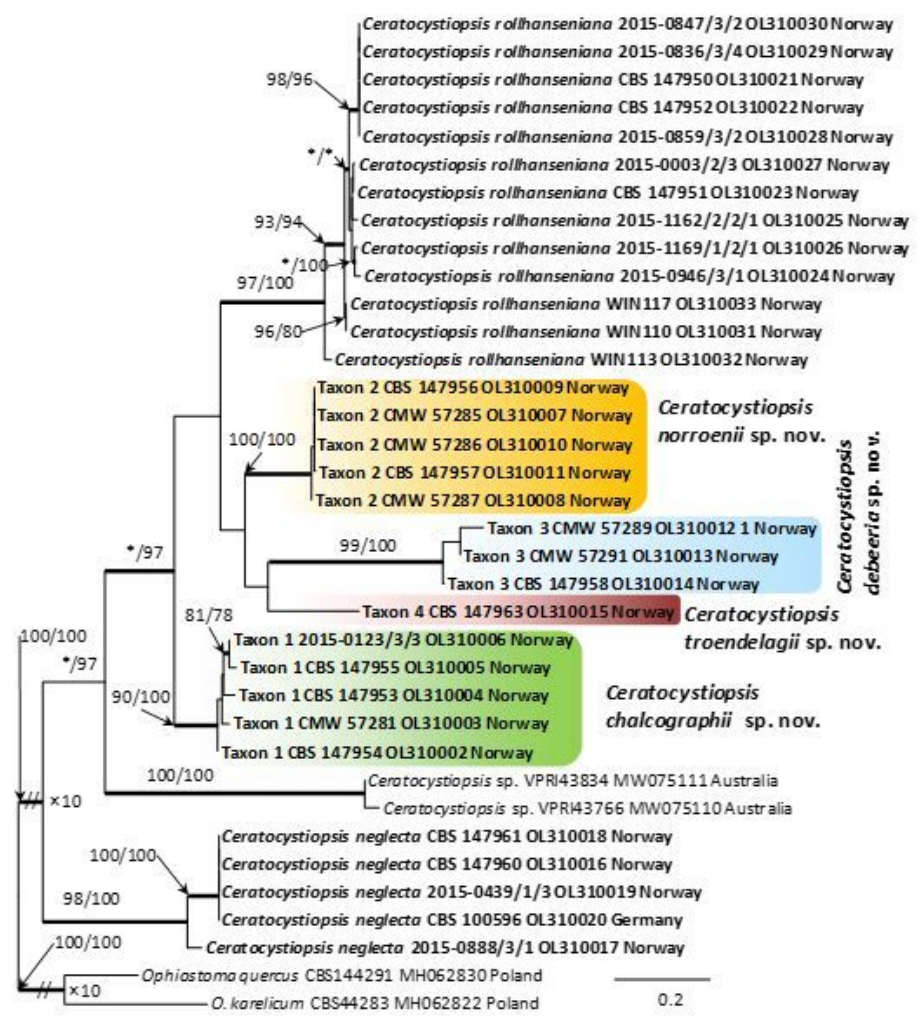

\section{Figure 6}

Phylogram obtained from Maximum Likelihood (ML) analyses of CAL data for the Ceratocystiopsis spp. Sequences obtained during this study are presented in bold type. The Bootstrap values $\geq 75 \%$ for ML and Maximum Parsimony (MP) analyses are presented at nodes as follows: ML/MP. Bold branches indicate posterior probabilities values $\geq 0.95$ obtained from Bayesian Inference (BI) analyses. *Bootstrap values $<75 \%$. The tree is drawn to scale (see bar) with branch length measured in the number of substitutions per site. Ophiostoma karelicum and O. quercus represents the outgroup in analyses of CAL. 


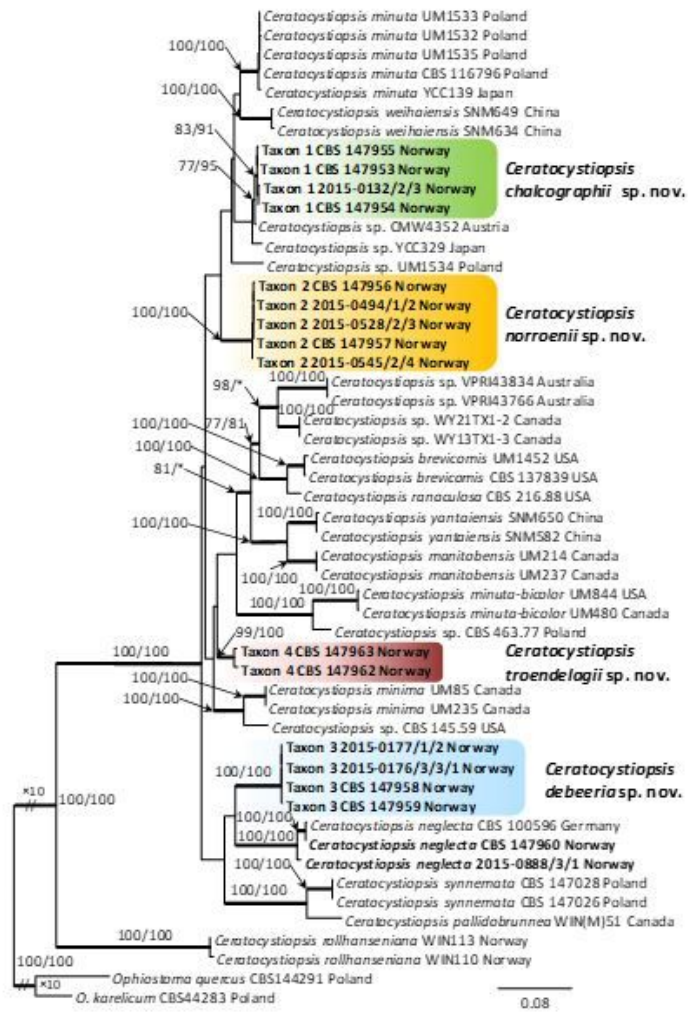

\section{Figure 7}

Phylogram obtained from Maximum Likelihood (ML) analyses of the combined datasets of TS1-5.8S-ITS2-28S+ßT data for the Ceratocystiopsis spp. Sequences obtained during this study are presented in bold type. The Bootstrap values $\geq 75 \%$ for ML and Maximum Parsimony (MP) analyses are presented at nodes as follows: ML/MP. Bold branches indicate posterior probabilities values $\geq 0.95$ obtained from Bayesian Inference (BI) analyses. ${ }^{*}$ Bootstrap values $<75 \%$. The tree is drawn to scale (see bar) with branch length measured in the number of substitutions per site. Ophiostoma karelicum and 0 . quercus represents the outgroup in analyses of the combined datasets of ITS1-5.8S-ITS2-28S+ßT. 

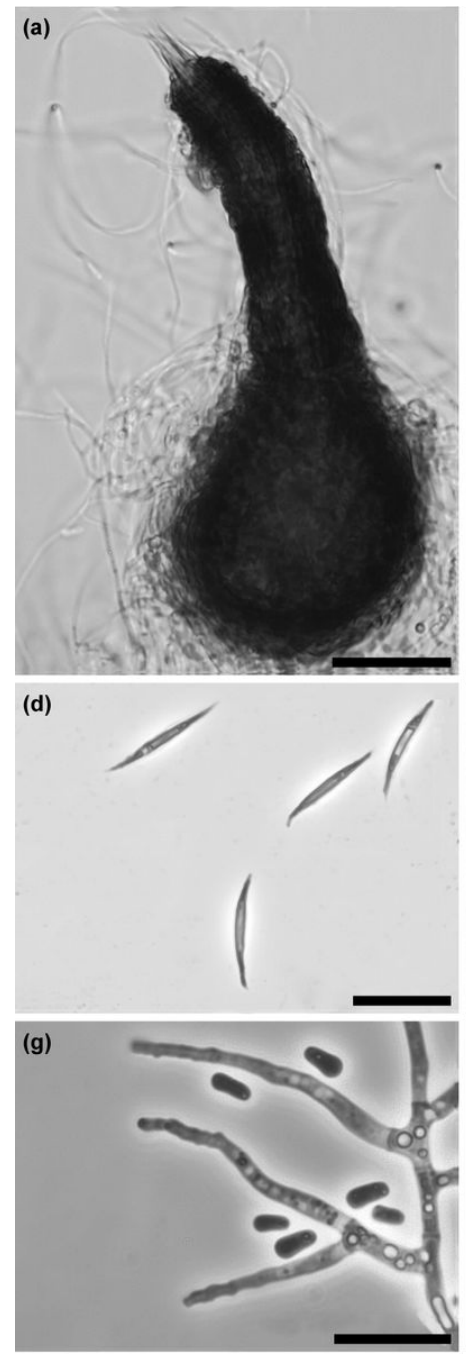

(b)

(c)
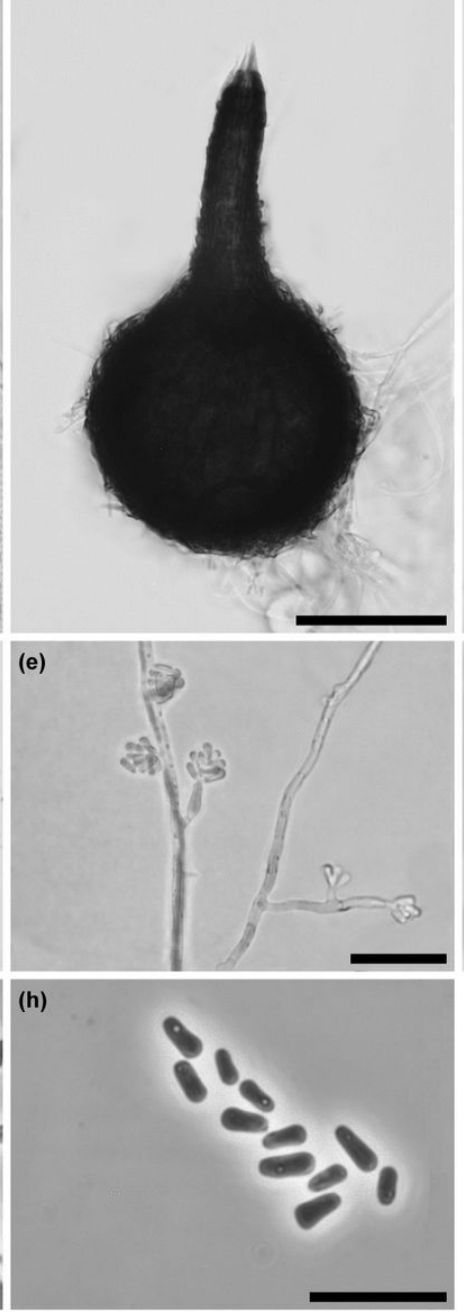

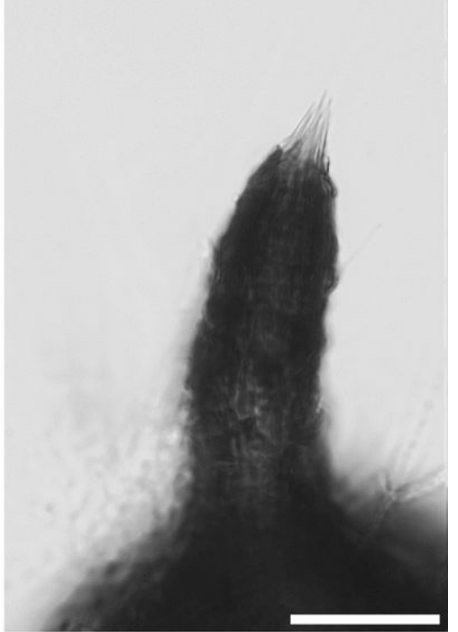

(f)

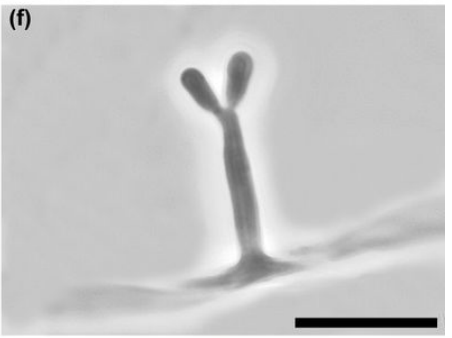

(i)

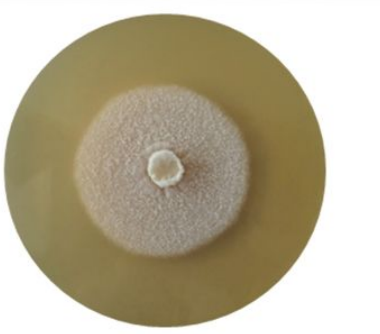

\section{Figure 8}

Morphological characteristics of Ceratocystiopsis chalcographii sp. nov. (CBS 147954, Taxon 1). a-b. Perithecium; c. Ostiolar hyphae; d. Ascospores; e-f. Micronematous conidiophores; g. Slightly branched micronematous conidiophores; $\mathrm{h}$. Conidia; i. Fourteen-day-old culture on MEA. Scale bars: $\mathrm{a}=25 \mu \mathrm{m} ; \mathrm{b}=$ $50 \mu \mathrm{m} ; \mathrm{c}=25 \mu \mathrm{m} ; \mathrm{d}=10 \mu \mathrm{m} ; \mathrm{e}=25 \mu \mathrm{m} ; \mathrm{f}-\mathrm{g}=10 \mu \mathrm{m}$. 

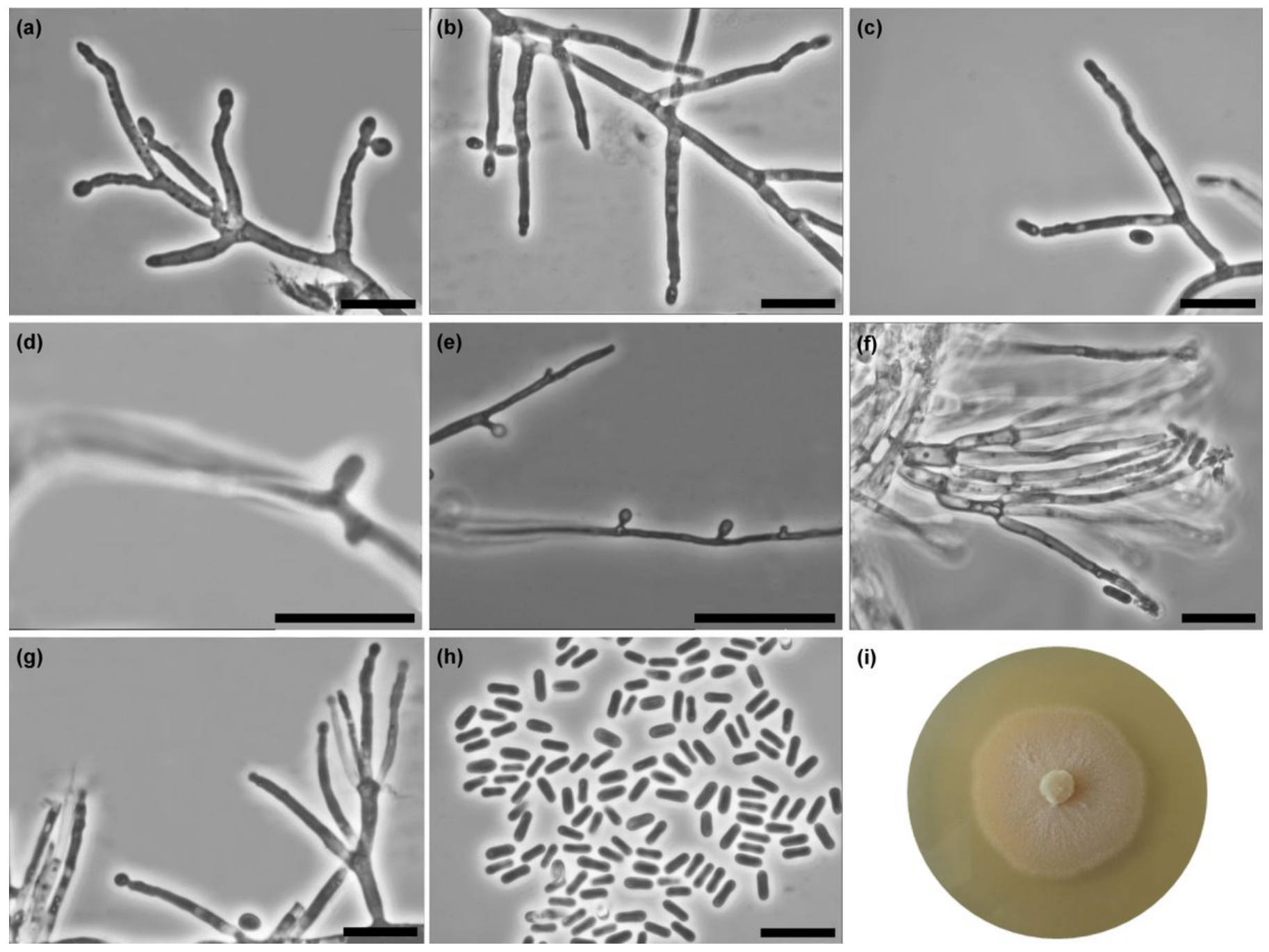

\section{Figure 9}

Morphological characteristics of Ceratocystiopsis norroenii sp. nov. (CBS 147956, Taxon 2). a-c. Simple (a, b) and slightly (c) branched micronematous conidiophores; d-e. Conidia arising directly from hyphae; f-g. Branching macronematous conidiophores; h. conidia; i. Fourteen-day-old culture on MEA. Scale bars: $a-d=10 \mu \mathrm{m}, \mathrm{e}=25 \mu \mathrm{m}, \mathrm{f}-\mathrm{h}=10 \mu \mathrm{m}$. 

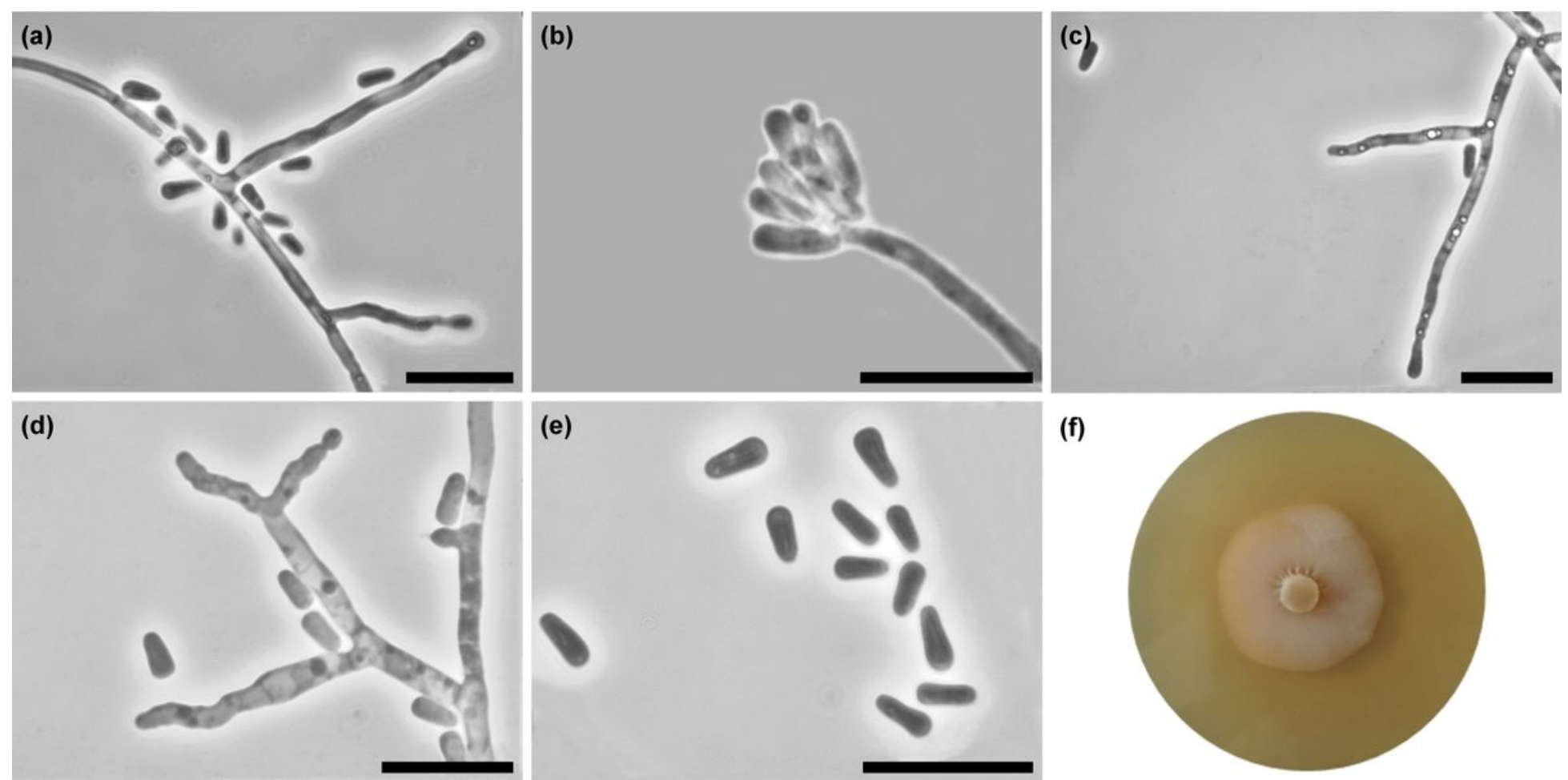

\section{Figure 10}

Morphological characteristics of Ceratocystiopsis debeeria sp. nov. (CBS 147958, Taxon 3). a-d. Simple (a, b) and slightly (c, d) branched micronematous conidiophores; e. Conidia; f. Fourteen-day-old culture on MEA. Scale bars: a-e $=10 \mu \mathrm{m}$.

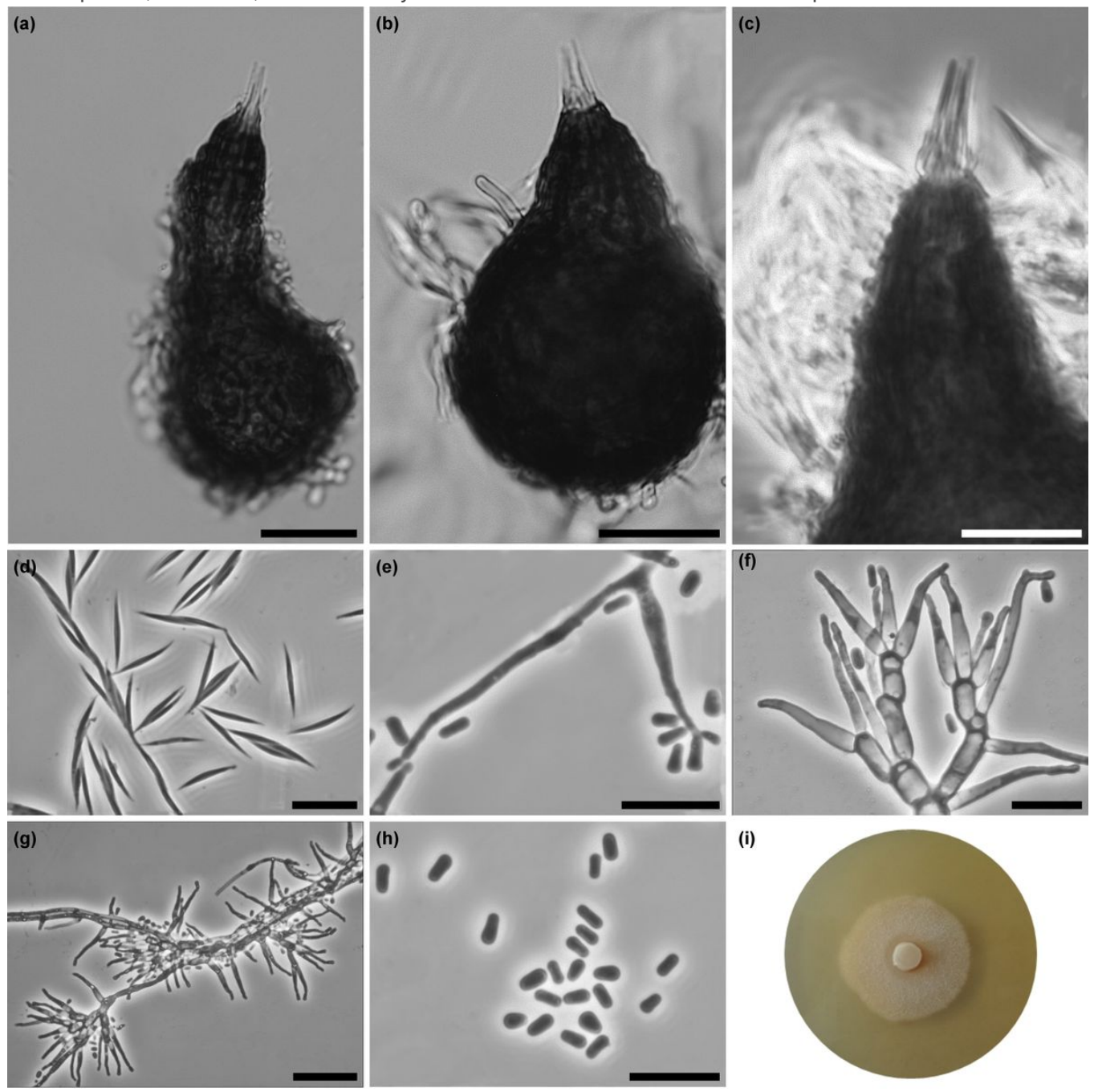


Figure 11

Morphological characteristics of Ceratocystiopsis troendelagii sp. nov. (CBS 147962, Taxon 4). a-b. Perithecium; c. Ostiolar hyphae; d. Ascospores; e. Micronematous conidiophores; $f-g$. Branching macronematous conidiophores; $h$. Conidia; i. Fourteen-day-old culture on MEA. Scale bars: $a-b=25 \mu m ; c-f=10$ $\mu \mathrm{m} ; \mathrm{g}=25 \mu \mathrm{m} ; \mathrm{h}=10 \mu \mathrm{m}$. 